This document is the accepted manuscript version of the following article:

Dong, X. P., Bengtson, S., Gostling, N. J., Cunningham, J. A., Harvey, T. H. P., Kouchinsky, A., ... Donoghue, P. C. J. (2010). The anatomy, taphonomy, taxonomy and systematic affinity of Markuelia: Early Cambrian to Early ordovician scalidophorans. Palaeontology, 53(6), 1291-1314. https://doi.org/10.1111/j.1475-4983.2010.01006.x

THE ANATOMY, TAPHONOMY, TAXONOMY AND SYSTEMATIC AFFINITY OF MARKUELIA: EARLY CAMBRIAN TO EARLY ORDOVICIAN SCALIDOPHORANS

by Xi-Ping Dong ${ }^{1}$, Stefan Bengtson ${ }^{2}$, Neil J. Gostling ${ }^{3,4}$, John A. Cunningham ${ }^{3}$, Thomas H. P. Harvey ${ }^{5}$, Artem Kouchinsky ${ }^{2}$, Anatoly K. Val'kov ${ }^{6}$, John E. Repetski ${ }^{7}$, Marco Stampanoni, ${ }^{8}{ }^{9}$ and Philip C. J. Donoghue $^{\star 3}$

${ }^{1}$ School of Earth and Space Science, Peking University, Beijing 100871, P. R. China

${ }^{2}$ Department of Palaeozoology, Swedish Museum of Natural History, Box 50007, SE-104 05 Stockholm, Sweden

${ }^{3}$ Department of Earth Sciences, University of Bristol, Wills Memorial Building, Queen's Road, Bristol BS8 1RJ, UK

${ }^{4}$ Present address: Department of Biological Sciences, SUNY Oswego, 133 Piez Hall, Oswego, New York 13126, USA

${ }^{5}$ Department of Geology, University of Leicester, University Road, Leicester LE1 7RH, UK

${ }^{6}$ Institute of Geology of Diamonds and Noble Metals, Siberian Branch of the Russian Academy of Sciences, 39 Prosp. Lenina, Yakutsk, 677891 Russia

${ }^{7}$ US Geological Survey, MS 926A, National Center, Reston, Virginia, VA 20192, USA

${ }^{8}$ Swiss Light Source, Paul Scherrer Institut, 5232 Villigen, Switzerland

${ }^{9}$ Institute for Biomedical Engineering, University of Zürich and ETH Zürich, Zürich, Switzerland

*author for correspondence: Department of Earth Sciences, University of Bristol, Wills Memorial Building, Queen's Road, Bristol BS8 1RJ, UK <phil.donoghue@bristol.ac.uk>

Abstract: Markuelia is a vermiform, annulated introvertan animal known as embryonic fossils from the Lower Cambrian to Lower Ordovician. Analysis of an expanded and revised dataset for Introverta shows that the precise position of Markuelia within this clade is dependent on the taxa included. As a result, Markuelia is assigned to the scalidophoran total group to reflect uncertainty as to whether it is a stem-scalidophoran or a stem-priapulid. The taxonomy of the genus is revised in order to provide an improved taxonomic framework for material assigned to Markuelia. Five species are recognised: M. secunda Val'kov, M. hunanensis Dong 
and Donoghue, M. lauriei Haug et al., M. spinulifera sp. nov. and M. waloszeki sp. nov. Finally, the preservation of Markuelia is evaluated both in the light of the taphonomy of the fossil embryos themselves, as well as in the light of experimental taphonomy of the priapulid Priapulus caudatus, which has been proposed as both a close relative and an anatomical analogue of Markuelia.

Key words: embryos, taphonomy, preservation, Priapulida, Scalidophoran, Introverta, taxonomy

EMBRYOS make for rare fossils and, hence, their recognition as elements of the fossil record has arrived very late. Among the first fossil embryos to be described as such were representatives of Markuelia (Bengtson and Yue, 1997), described originally by Val'kov (1983) as globular microfossils. Without access to a scanning electron microscope, Val'kov was not able to make out the structural details of this organism, but he later reported an outer layer with a smooth surface and an inner one with a complex pattern of parallel double-walled septa (Val'kov, 1987). Bengtson and Yue (1997) found that the globular fossils were in fact late-developmental embryonic stages of a segmented worm-like organism, coiled up within a spherical outer membrane. The anatomy of Markuelia has subsequently been elucidated more fully, and phylogenetic analysis has revealed Markuelia to be closely related to the living scalidophoran phyla (Kinorhyncha, Loricifera, Priapulida) (Dong et al., 2004; Dong et al., 2005; Donoghue et al., 2006b). Markuelia has been shown to have a broad stratigraphic and geographic distribution, extending from the Lower Cambrian of Siberia, through the Middle Cambrian of China and Australia, to the Lower Ordovician of the United States (Donoghue et al., 2006a).

Our aim is to provide an improved taxonomic framework for the material currently referred to Markuelia, which exhibits anatomical variation that is currently poorly delineated by the existing species concepts. We also seek to establish whether the anatomical characteristics used in resolving the affinity of $M$. hunanensis are peculiar to this species or whether they are features of the genus as a whole. We recognize five species: M. secunda Val'kov, M. hunanensis Dong and Donoghue, M. lauriei Haug et al., M. spinulifera sp. nov. and M. waloszeki sp. nov., which share features of gross anatomy, scalid arrangement and tail morphology. Finally, we consider the prevalence of embryos of Markuelia in light of empirical evidence of taphonomy from the fossils themselves, and in light of an experimental taphonomy study of priapulids, which have been proposed as close living relatives and anatomical analogues of Markuelia. 


\section{1}

\section{MATERIALS AND METHODS \\ Localities}

The fossil embryos were obtained from the Lower Cambrian Pestrotsvet Formation at localities in the Aldan River Basin, Siberia; from the Middle Cambrian Inca Shale at North Rogers Ridge, and the Beetle Creek and Monastery Creek formations at Mount Murray, Georgina Basin, northern Australia; from the Middle Cambrian Huaqiao Formation and Late Cambrian Bitiao Formation of Wangcun, Hunan Province, south China; and from the Lower Ordovician Vinini Formation of Battle Mountain, Carlin, Nevada, USA. Further locality details are provided by Donoghue et al. (2006a).

\section{Fossil recovery and analysis}

The fossil materials on which this study has been based were recovered through use of buffered acetic acid (6-10\%) or buffered formic acid (c. 10\%). The embryos were recovered subsequently by manually sorting through the acid insoluble residue under a binocular microscope. Fossils were then coated with goldpalladium for examination using a scanning electron microscope, or remained uncoated for examination using an environmental scanning electron microscope. Some of the specimens were also examined by synchrotron radiation X-ray tomographic microscopy (SRXTM) (Donoghue et al., 2006b) on the X04SA and X02DA (TOMCAT) beamlines at the Swiss Light Source, Paul Scherrer Institute, Villigen, Switzerland.

\section{Experimental taphonomy}

Adults of the priapulid Priapulus caudatus were trawled from Gullmarsfjorden, Sweden. The ovaries were dissected from the females and macerated to liberate the eggs which were then mixed with sperm collected from the males. Excess sperm was washed off after 30 minutes to prevent polyspermy. The developing embryos were kept in the dark, at $6^{\circ} \mathrm{C}$ with a daily water change. Fertilisations were set up at different time periods, so that different stages of development would be present and included in the lysing procedure for the taphonomy experiment. Lysis was achieved through exposure of the embryos to anoxic seawater for a period of 72 hours. The embryos were subsequently placed in vials with oxic or anoxic artificial seawater, as appropriate. These vials were then maintained at $15^{\circ} \mathrm{C}$ and a sample was taken from the parallel sets at weekly intervals, to six weeks, in order to analyse the progressive degradation of the embryos and larvae. Each sample was fixed in glutaraldehyde and prepared for thin sectioning and scanning electron microscopy. 


\section{Gross Anatomy}

Markuelia is known only from spherically to sub-spherically enrolled embryos, frequently encased in their fertilization envelope, preserved by replication and/or replacement of soft tissues by calcium phosphate. These embryos range in size from a minimum diameter of $275 \mu \mathrm{m}$ (M. lauriei) to over $400 \mu \mathrm{m}(M$. hunanensis, M. secunda, M. spinulifera). At this stage of development, Markuelia is a densely annulated, bilaterally symmetrical vermiform metazoan, tightly coiled in either an S-shaped loop or an inverted Sshaped loop. A distinct head and spine-bearing tail occur terminally at opposing ends of the principal body axis but, in the coiled state of the embryo, the head and tail are juxtaposed and orientated in opposing directions. The trunk is oblate in cross-sectional profile and approximately $150 \mu \mathrm{m}$ in width, becoming increasingly dorso-ventrally compressed at the anterior and posterior extremities. It is possible that dorsoventral compression is an artefact of the close-packing of the embryo into a spherical fertilization envelope.

Head

The anterior end of the embryo, as observed in some species, is characterized by a terminal mouth cone surrounded by circumferential rings of spines, termed scalids, where the position of the scalids intercalates those of the preceding and proceeding rings. The precise number of rings varies between the different species of Markuelia, from three to eight. In the species in which it can be determined, namely $M$. hunanensis and M. lauriei, 25 scalids comprise the three rings closest to the mouth cone: eight in the ring adjacent to the mouth cone, eight in the second ring, and nine scalids in the third. The scalids show evidence of post mortem collapse, indicating that they were lightly cuticularised and that the cuticular envelope collapsed to two-dimensions upon decay of the underlying tissues. The scalids are of simple spine-like morphology in all species of Markuelia, where they can be observed, except $M$. spinulifera, where the surface of the scalid is itself covered by smaller scale spines.

The position of the mouth cone varies within taxa, reflecting an everted position where it occurs at the anterior extreme of the larva, flanked by externally positioned scalids, and an inverted position where it is enclosed within a terminal lumen. This portion of the larva represents the introvert, and it is devoid of the annulation that is so conspicuous of the conjoining trunk. 

1

The trunk is vermiform and annulated, and though it maintains an approximately constant width throughout much of its extent, it tapers towards the tail end, becoming dorsoventrally flattened. We have used the noncommittal term annulation in describing the metameric nature of the trunk cuticle in Markuelia; however, as noted previously (Dong et al., 2004; Dong et al., 2005), we do not exclude the possibility that the anatomy of the trunk was more universally metameric, or segmented. Evidential support for metamerism may be found in the septa that extend internally from the cuticle wall (Dong et al., 2004; Dong et al., 2005) and, further, that there are internal anatomical structures preserved in register with the annulation in two specimens of $M$. secunda (Bengtson and Yue, 1997).

The precise number of annuli is known for seven specimens because only these specimens preserve both the head and the tail. The majority of these specimens are representatives of $M$. hunanesis, for which annulation counts of $56,60,64,68$ have been obtained. The one specimen of $M$. secunda for which annuli could be counted possessed 75 annulations, and two specimens of M. lauriei possessed 72 and 86 annulations, respectively. Although sample size is very small, the degree of variation encountered in $M$. hunanensis could indicate a mode of growth in which annuli are formed sequentially from a growth zone. Sequential segment addition is considered plesiomorphic for arthropods, in contrast to the derived mode of simultaneous segment specification known from long germ band insects (e.g. Peel, 2004). Taking such a model for Markuelia, the various specimens could represent different growth stages - although intraspecific variation might also be a factor, as it is in some extant myriapod arthropods (see Fusco, 2005) - while the absence of preserved embryos with smaller numbers of annuli could reflect a comparatively late timing of the development of a robust cuticle. Alternatively, embryonic annulus development in Markuelia might have been more similar to that in the extant nematode Caenorhabditis elegans, where a variable number of annulus furrows appear to be formed more or less simultaneously via the constriction of epidermal actin fibre bundles during embryo elongation (see Costa et al., 1997).

Some species of Markuelia possess posteriorly directed spines projecting from the annuli. These are most extensively developed in $M$. secunda, where as many as five may be present on each annulus, aligned such that the spines of succeeding annuli intercalate the position of those of the preceding annulus, and the spines on every third annulus are in register. In M. lauriei the spines are present but much fewer in number, and in M. hunanensis such spines are absent. 
Tail

All species of Markuelia possess three bilaterally arranged, nested pairs of terminal spines which are recurved to varying degrees. The three pairs of spines are arranged around a terminal lumen that has been traced extending into the trunk in tomographic sections, and interpreted as the anus and digestive tract (Donoghue et al., 2006b). One pair of spines is positioned dorsally with respect to the anus and is shorter than the other two pairs of spines in some species. The second pair of spines lies ventrally with respect to the anus; these spines are typically more narrowly based than the other two pairs and are only recurved close to the tip. The third pair is positioned laterally with respect to the anus. The consistency in number, position and overall form of these tail spines strongly suggests that there is homology between the spines of the Markuelia species; we therefore propose a scheme of homology whereby the three pairs of spines are termed the dorsal, ventral and lateral pairs respectively. The morphology of homologous spines varies between species: they are more elongate in $M$. hunanensis and $M$. spinulifera, while they exhibit a comparatively squat morphology in M. lauriei, M. waloszeki and M. secunda.

\section{Reconstruction}

We have produced a generalized reconstruction for the embryo, unfurled as though it had hatched (Text-fig. 1). This reconstruction is based on the combined evidence from all species of Markuelia, but it has been based most closely on Markuelia hunanensis for which there is the greatest evidence of introvert, trunk and tail morphology. The anterior end is shown in three positions representing the cycle of eversion of the introvert; a cut away view of the inverted position is also shown. In the inverted position, the scalids point anteriorly, but lay against the body and pointing posteriorly as they are everted, a character that serves to distinguish scalids from pharyngeal teeth (Nielsen, 2001, p. 332).

\section{THE AFFINITY OF MARKUELIA}

When Bengtson and Yue (1997) identified Markuelia as a fossil embryo for the first time, they considered its affinity to annelids and lobopods, while Conway Morris (1998) speculated that Markuelia might be an embryonic halkieriid. The description of more complete material constrained further speculation, leading to the conclusion that Markuelia was a member of Introverta. Within this framework, initial cladistic analyses including fossil and living ecdysozoans indicated that Markuelia is a stem-priapulid (Dong and Donoghue, 2002), but subsequent analyses suggested a stem-scalidophoran affinity (Dong et al., 2004; Dong et al., 
1

2005). This conclusion was robust to the elucidation of the composition and arrangement of the introvert scalids (Donoghue et al., 2006b), but these phylogenetic conclusions have always been sensitive to the fact that the anatomy of Markuelia is not only incompletely known, but is known only from embryonic material. Sensitivity analysis of the datasets has shown that the phylogenetic position of Markuelia is sensitive to the sets of taxa included in analyses, in some instances resolved as stem-priapulids and, more precisely, as a sister taxon to palaeoscolecids (Cobbett et al., 2007). This may provide some support for Huang's speculative suggestion that Markuelia species are embryos of palaeoscolecids (Huang et al., 2006). Indeed, the presence of bilaterally symmetrical pairs of perianal spines in both Markuelia and some palaeoscolecids potentially provides evidence of a close relationship. However, the numbers and proportions of scalids in the head, and spines in the tail of Markuelia indicate that character homology and close kinship are dubious (see Harvey et al., in press). Given the sensitivity of the dataset to taxon inclusion, and the recent description of a greater number of scalidophoran taxa, we compiled a revised and expanded cladistic dataset for cycloneuralians, including representative fossil and living panarthropods, and Gastrotricha as a root. This dataset has been described elsewhere (Harvey et al., in press) but it has been augmented with codings for Markuelia based on the anatomical information we present here (Appendix).

An unweighted parsimony analysis of the dataset, initially including just the extant cycloneuralians and panarthopods yielded a single most-parsimonious tree (MPT; 131 steps; Cle 0.75 ; RI 0.82; Text-fig. 2A) that is compatible with the previous morphological analyses (Dong et al., 2004; Dong et al., 2005; Donoghue et al., 2006b; Harvey et al., in press; Lemburg, 1999; Wills, 1998) and some of the most comprehensive molecular phylogenies (e.g. Dunn et al., 2008); it disagrees with some molecular phylogenies but these have been based on very little data (e.g. Park et al., 2006; Sørensen et al., 2008).

Inclusion of Markuelia again yields a single MPT (136 steps; Cle 0.72; RI 0.80; Text-fig. 2B) in which it is resolved as the sister taxon to Scalidophora. Inclusion of representative stem-arthropods and a putative stem-onychophoran results in 16 MPTs (143 steps; Cle 0.70 ; RI 0.80 ) that differ only in terms of the relative relationships of the extinct and extant panarthropods. Tardigrada is solely responsible for the conflict between the MPTs, and the exclusion of this leaf results in a single MPT (138 steps; Cle 0.72; RI 0.80; Textfig. 2C); the stem-scalidophoran position of Markuelia remains stable throughout. Inclusion of a large number of extinct introvertans results in 276 MPTs (209 steps; Cle 0.54; RI 0.72), the strict consensus of which is not well resolved but unequivocally identifies Markuelia as a member of the priapulid total-group (Text-fig. 2D). Reweighting according to the rescaled consistency indices of the unweighted analysis produced 2 MPTs at 
89.47 steps Cle $0.73 ; \mathrm{RI} 0.86$ compatible with two trees from among 276 in unweighted analysis that differ only in the relative relations of Priapulites and Priapulopsis (the strict consensus of these two MPTs is shown in Text-fig. 2E). However, this scheme of relationships is sensitive to the taxon set, and the exclusion of just a single taxon can lead to a radically different solution. For instance, exclusion of Cricocosmia produces 26 MPTs, the strict consensus of which resolves palaeoscolecids as stem-nematomorphs, and Markuelia together with a rump of extinct introvertans (Tylotites, Scolecofurca, Louisella, Ottoia, Corynetis, Selkirkia, Maotianshania and Tabelliscolex) as stem-scalidophorans (208 steps; Cle 0.54; RI 0.72; Text-fig. 2F).

These analyses demonstrate that a precise resolution of the phylogenetic affinity is contingent upon the tests of character polarity and congruence provided by the wealth of other fossil introvertans. Unfortunately, however, the anatomy of the fossil introvertans is not well resolved, particularly with regard to the anatomy and scalid arrangement of the introvert itself. This does not occur because of the vagaries of fossilization but because specialists have failed to resolve and describe these characters from the original material (Conway Morris, 1977; Maas et al., 2007b are notable exceptions) and it is not possible to glean this information from figures alone. Until this situation is revised it will not prove possible to resolve the phylogenetic position of Markuelia or the remaining fossil introvertans more precisely. Traditionally, these taxa would be assigned to the scalidophoran stem-group. This is precisely in accordance with the original utility of the stem-group as it was formulated by Hennig as a dustbin for fossil taxa that failed to show the necessary characteristics diagnostic of the respective crown-groups, but for which it was not possible to distinguish whether those characters were primitively absent (they had not yet evolved) or whether they had merely rotted away and so were not preserved (Donoghue, 2005; Hennig, 1981). However, the stem-group has since acquired an exclusively phylogenetic meaning, eschewing its use as a qualification of systematic classification (Donoghue, 2005). Thus, in such instances, it is most appropriate to assign taxa such as Markuelia to the scalidophoran total-group (Donoghue and Purnell, 2009) to better express equivocation over its systematic classification given that it may be a stem-scalidophoran or a stem-priapulid.

\section{THE PRESERVATION OF MARKUELIA}

Specimens of Markuelia are preserved at various stages of decay. In a few specimens the entire anatomy of the animal, including the head, is preserved (Text-fig. 3A). The head is consistently less well preserved than the other parts of the animal's external anatomy; where it is present it invariably shows signs of decay- 


\section{1}

related collapse (Text-fig $3 \mathrm{C}$ ). More commonly, the head is absent from otherwise well preserved embryos (Text-fig. 3B) indicating that it is the first part of the organism to be destroyed by decay.

Embryos that have decayed to a greater extent exhibit a continuum of increasing collapse and shrinkage (Text-fig. 3D-F). As this process continues the annuli become increasingly indistinct and the interior of the embryo may shrink to approximately $20 \%$ of its original diameter. In some cases the shrunken embryo is attached to the chorion by phosphatic filaments. These filaments may represent fungal hyphae or filamentous bacteria (see discussion in Xiao and Knoll (1999); these features will be termed 'filaments' hereafter).

Specimens may be encased within spheres that we interpret as the chorion, a membrane enveloping the developing embryo in life. In some of the specimens in our collections the chorion is entirely absent (e.g. Text-fig. 3B). In other cases it is present but is broken open; some of these specimens reveal a Markuelia embryo within (Text-fig. 3D), while others are shown to be empty, and further specimens contain filaments (Text-fig. 3G). Our collections also contain a large number of unbroken spheres, which are most probably chorions, and these may or may not be deformed (Text-fig. $3 \mathrm{H}-\mathrm{I})$.

Wilby and Briggs (1997) identified three distinct calcium phosphate microfabrics. These are (1) substrate microfabric where the tissues themselves are replaced by calcium phosphate, (2) intermediate microfabric where the tissue is mineralized but impressions of decay microbes are preserved, and (3) microbial microfabric where microbes infesting the tissue become mineralized. There is a general decrease in spatial fidelity of preservation from substrate to intermediate to microbial microfabric because preservation of relatively large decay microbes limits fidelity. All three of these microfabrics are present in specimens of Markuelia (Text-fig. 4). One specimen (Text-fig. 4D) has a layer of compressed dumb bell-shaped structures replicating the chorion. These structures are reminiscent of bacterially-induced precipitates of calcite (Chafetz and Buczynski, 1992) but they are composed of calcium phosphate and are geometrically distinct. We interpret them as a bacteria.The spatial fidelity of preservation seems to be independent of amount of decay. For example, some specimens have undergone very little decay and yet the preservational fabric is characterized by coarse spherulitic crystallization (Text-figs 3D, 4C). 
The chorion is consistently preserved in fine crystallites with a substrate microfabric (Text-fig. 3D-I). The inner surface may, however, be coated by coarser spherules (Text-fig. 3F-G). The interior may be preserved in as much detail as the chorion but it is frequently less well preserved.

\section{Mechanism of preservation}

In order for high fidelity preservation of labile soft tissue to occur, of the kind observed in Markuelia, rapid authigenic mineral precipitation is required (Briggs, 2003). Experimental studies (Briggs and Kear, 1993, 1994; Hof and Briggs, 1997; Kear et al., 1995; Sagemann et al., 1999) have produced authigenic phosphatization in the laboratory, thus allowing an understanding of the controls on this kind of preservation. The process relies upon steep geochemical gradients established by decay microbes (Sagemann et al., 1999) and requires specific conditions in order for calcium phosphate, rather than calcium carbonate, to be precipitated. This is the calcium carbonate - calcium phosphate switch (Briggs and Wilby, 1996). The key conditions needed to set the switch to calcium phosphate are (1) sufficient concentration of phosphate to inhibit calcite or aragonite precipitation, (2) reduced pH, and (3) a closed system (Briggs and Kear, 1993, 1994; Briggs and Wilby, 1996). While experimental studies (Briggs and Kear, 1993, 1994) have shown that $\mathrm{pH}$ is a major control in calcium phosphate precipitation, it is insufficient to induce calcium phosphate precipitation if the phosphorous concentration is too low (Briggs and Wilby, 1996). Indeed, in the absence of a significant external source of phosphorous, experimental studies have been able to yield calcium phosphate precipitation only in crustaceans (Briggs and Kear, 1993, 1994; Hof and Briggs, 1997) and (to a lesser extent) squid (Kear et al., 1995), where the large carcasses could act as a phosphorous source. This would suggest that an external source of phosphorous must be invoked to explain the preservation of embryos, which obviously lack a large, phosphate-rich carcass.

Experiments on lobster eggs provide evidence that relates specifically to the preservation of eggs and embryos. At the time of writing these experiments have failed to produce calcium phosphate precipitation. However, mineralization of the chorion in calcium carbonate and calcium phosphate has been observed (Martin et al., 2003, 2005), albeit in coarse spherules rather than the substrate microfabric seen in the chorions of fossils. In another series of experiments (Martin et al., 2004) sediment particles became attached to the chorion. While the experiments have yielded no information on preservation of the interior, either of these mechanisms may represent an essential first stage in preservation that is needed to prevent collapse (Martin et al., 2003). 
The mechanisms of preservation described above can account for the variation observed in our collections. As the chorion is consistently preserved in crystals at least as fine as those of the interior, and because its amount of decay seems unrelated to that of the interior, it is suggested that the chorion is mineralised in a distinct, initial stage of replacement. The interior of the embryo may be preserved later; the length of time between these two phases of mineralization may be an important control on the amount of decay observed in the interior. Interior mineralization may preserve filaments that grow during or after decay or may not occur at all, the latter resulting in empty chorion. Gostling et al. (2008) have shown that the rates of decay of the chorion and embryo are not linked and Raff et al. (2008) have shown that distinct microbial communities infest the embryo and chorion. Hence, in fossil assemblages the presence of chorions without embryos or embryos without chorions.

\section{Comparative taphonomy}

While it may be possible to explain what is fossilised of the embryos of Markuelia in terms of replication of organic substrates by various modes of bacterially mediated authigenic mineralization, what it does not explain is why these stages of embryonic development are preserved in preference to earlier embryonic and postembryonic development. There are few candidate fossils representing earlier stages of the embryology of Markuelia (Dong et al., 2004; Dong et al., 2005) and their characteristics are so generic that they are uninformative. Furthermore, the security with which they are associated with Markuelia amounts to little more than co-association (Donoghue and Dong, 2005). Experimental investigation of the relationship between embryology and taphonomy has shown that preservation potential varies with development and, in some instances, the earliest stages of embryology have the greatest preservation potential (Gostling et al., 2009; Gostling et al., 2008; Raff et al., 2006). However, in Markuelia it is the late embryonic stage that evidently had the highest fossilization potential given that it is the only fossil embryo known from a broad geographic and stratigraphic range of localities, extending from the Lower Cambrian of Siberia, through Middle Cambrian of Australia and China, Late Cambrian of China, to Early Ordovician of the United States (Donoghue et al., 2006a). This has been explained as an artefact of the precocious development of a cuticle in the embryo, the cuticle serving as a suitable substrate for mineralization associated with exceptional preservation, the effect of the fertilization envelope in establishing a geochemical microenvironment necessary for the initiation of mineralization (Donoghue et al., 2006a). It remains possible, however, that cuticle is relatively decay resistant and, thus, that it is available as a substrate for replication by nucleating 
mineral crystals long after tissues of other composition have decayed away (Gostling et al., 2009), perhaps providing the ions necessary for mineralization to occur.

To determine the relative preservation potential of cuticle in an embryo such as Markuelia, we undertook a decay experiment based on the priapulid Priapulus caudatus, which is both an extant relative and analogue of the embryo of Markuelia. In fresh larvae, where the introvert was retracted, the cuticle bearing larval spines is positioned internally, just as it is in Markuelia (Text-fig. 5A). However, as decay progressed the visceral portion of the head became detached from its surrounding cuticle, until the muscles of the introvert were retracted, whilst the spines remained everted (Text-fig. 5B). As decay progressed the muscle decayed to nothing until all that remained was cuticle. Eventually even the cuticle was subject to decay collecting a thick mantle of bacteria (Text-fig. 5C). During decay, the muscles and internal organs pulled away from the cuticle (as has also been observed in stem-priapulids by Conway Morris, 1977).

Similar decay resistance was seen in the embryo (Text-fig. 5D-F). As in the larvae, the embryonic cuticle showed signs of shrinkage, even in fresh material (Text-fig. 5D). In both cases this was interpreted as an artefact of thin sectioning. The cells were distinct in the fresh embryo (Text-Fig. 5D), but as decay progressed they began to coalesce and shrink and the chorion began to lose its shape in some specimens, becoming less spherical as the embryo shrank (Text-fig. 5E). Decay progressed until the chorion contained only the cuticle and some shrunken decayed organic matter (Text-fig. 5F). Eventually this decayed organic matter was lost and then, finally, the remaining cuticle decayed and the chorion was all that was left. The progression of decay was difficult to observe from surface morphology, as specimens could have corresponded to almost any thin section shown in Text-fig. 5D-F.

The embryos and larvae showed signs of increasing disruption to the cuticle and the internal cells/organs. The embryos showed signs of shrinkage of the cells until all that remained was cuticle inside the chorion. However, even after 6 weeks of optimal decay conditions there were individuals that were recognizable as embryos. This is virtually identical to the condition we observe in Markuelia, where all that appears to be preserved is cuticle within a chorion. Hence it appears that the fossilization of Markuelia is not perhaps comparable to the preservation of cleavage and gastrula-stage embryos from deposits such as the Ediacaran Doushantuo Formation (Hagadorn et al., 2006; Xiao et al., 1998) and the Cambrian Kuanchuanpu Formation (Bengtson and Yue, 1997; Steiner et al., 2004). Rather, it reflects the mineral replication of cuticle that is more comparable to 'Orsten'-style fossilization of the 3D cuticles of microscopic arthropods (Maas et 
al., 2006), though preservation potential may have been increased due the enclosure of the larva within a chorion facilitating the development of a geochemical microenvironment of concentrated ions and microbial activity necessary for diminishing autolysis and enhancing mineral replication of cuticle (Donoghue et al., 2006a; Gostling et al., 2009; Gostling et al., 2008; Raff et al., 2008; Raff et al., 2006).

\section{SYSTEMATIC PALAEONTOLOGY}

The specimens figured in this paper are located in the following repositories: Geological Museum of Peking University, China (GMPKU), National Museum of Natural History, Smithsonian Institution, Washington DC, USA (USNM), Swedish Museum of Natural History (NRM), Commonwealth Palaeontological Collections, Bureau of Mineral Resources, Canberra (CPC) and Institute of Palaeontology, Bonn University (UB).

NEPHROZOA Jondelius et al., 2002

ECDYSOZOA Aguinaldo et al., 1997

INTROVERTA Nielsen, 1995

SCALIDOPHORA Lemburg, 1995

Genus MARKUELIA Val'kov, 1983 sedis mutabilis

Type species. Markuelia secunda Val'kov, 1984

Stratigraphical range and distribution. Lower Cambrian of Siberia, Middle Cambrian of China and Australia, Late Cambrian of China, Lower Ordovician of the United States.

Emended diagnosis. Wormlike animal with profusely annulated (about 56-86 annulations) trunk that coiled in an inverted S-shaped or S-shaped loop into a sphere, with anterior and posterior ends juxtaposed laterally. The posterior end with three pairs of bilaterally arranged, terminal spines.

Remarks. Markuelia secunda was first described as a fossil embryo by Bengtson and Yue (1997), although it had earlier been figured and briefly described as chambered organism of unknown affinities by Val'kov (1983) and subsequently figured several times by Val'kov and other Russian scientists (Bengtson and Yue, 
1997). The description of M. secunda by Bengtson and Yue (1997) stated that the chambers are segments of a wormlike animal that is tightly looped into a sphere. The two ends of the body form an inverted S-shaped double loop on the opposite hemisphere. The anterior end is not well preserved in the available specimens. The posterior end has modified segments, each with two symmetrically placed processes that join into a kind of posterior comb. The (trunk) segments carry short conical spines. Typically, a spine recurs in similar position on every third segment. Additional specimens of Markuelia demonstrate that the trunk may coil in both directions, resulting in mirror-imaged forms (see Donoghue et al. 2006a). The arrangement where the head (when viewed pointing upwards) is to the left of the tail is here defined as the L-form (equivalent to an S-shaped loop); the opposite arrangement is the R-form (equivalent to an inverted S-shaped loop). Furthermore, SRXTM studies show that $M$. secunda has another unexposed pair of spines, giving it a total of three pairs of terminal spines, the same as in the other species of Markuelia (see Donoghue et al. 2006b). The hundreds of specimens of Markuelia found from Middle and Late Cambrian in western Hunan, China (Dong et al., 2004; Dong et al., 2005), from Middle Cambrian in Georgina Basin, northern Australia and from Tremadocian, in Nevada, USA (Donoghue et al., 2006a) all lack broad conical trunk spines of this kind, except for M. waloszeki. We therefore conclude that these are the character of the species $M$. secunda rather than that of the genus Markuelia. We assign Markuelia to Scalidophora sedis mutabilis to reflect the uncertainty as to whether it represents a stem-scalidophoran or a stem-priapulid as discussed above.

\title{
Markuelia secunda Valkov, 1984
}

Text-fig. 6

\author{
v.1983 Markuelia cf. prima Val.; Khomentovsky et al., p. 28 [nomen nudum] \\ v.1983 Markuelia secunda Val.; Khomentovsky et al., p. 29 [nomen nudum] \\ v.1983 Markuelia prima Valkov; Val'kov, Pl. fig. 14 [nomen nudum] \\ v.1983 Markuelia secunda Valkov; Val'kov, PI. fig. 15-17 [nomen nudum] \\ V*1984 Markuelia secunda Valkov, 1983; Val'kov \& Karlova, pp. 23-24, PI. 2, Fig. 15 \\ v.1984 Markuelia prima Valkov, 1983; Val'kov \& Karlova, PI. 2, Fig. 15 [nomen nudum] \\ v.1987 Markuelia secunda Valkov, 1983; Val'kov, p. 116, PI. 14, fig. 11-13, Text-fig. 16
}




\section{1}

.1989 Markuelia prima Val.; Missarzhevsky, p. 211, PI. 30, fig. 4

v.1990 Markuelia secunda Valkov, 1987; Khomentovsky et al., pp. 30-31, PI. 4:3-6

1993 Markuelia prima; Khomentovsky and Karlova, p. 40, fig. 10

1993 Markuelia secunda; Khomentovsky and Karlova, p. 33, fig. 3

v.1997 Markuelia secunda Valkov, 1987; Bengtson and Yue, pp.1647-8, fig. 2a, b

v.1998 Markuelia secunda; Conway Morris, fig. 2a, b

v.2005 Markuelia secunda; Dong et al., p. 472, fig. 2h, i

v.2005 Markuelia secunda; Donoghue and Dong, pp. 90-1, fig. 4d, e

v.2006a Markuelia secunda; Donoghue et al., pp. 233-5, fig. 1f-j

v.2006b Markuelia secunda; Donoghue et al., pp. 681-2, fig. 2i, j

v.2007 Markuelia; Barton et al., fig. 10.8

Holotype. Val'kov and Karlova 1984, PI. 2, Fig. 15, No. $762 / 37$ (see under "Remarks").

Type locality and horizon. Height 1291 m, River Gonam, Aldan River Basin, southern Yakutia, Siberia. Base of the Pestrotsvet Formation, Lower Tommotian, Lower Cambrian.

Additional material. NRM X2239, NRM X2240, NRM X3803 (all three from the base of the Pestrotsvet Formation, Dvortsy section, left bank of the Aldan river, $4-5 \mathrm{~km}$ upstream of the mouth of the Dyalkhakh river); NRM X3801, NRM X3802 (both from the base of the Pestrotsvet Formation, at a height of $1291 \mathrm{~m}$, on the right side of the Gonam river, $30 \mathrm{~km}$ from its mouth), NRM X3804, NRM X3805 (both from the base of the Pestrotsvet Formation, left bank of the Aldan river, $7 \mathrm{~km}$ upstream of the mouth of the Ulakhan-Sulugur river).

Emended diagnosis. Markuelia species with short, conical spines on trunk annuli and a relatively long central pair of tail spines. 
Description. The embryos are all spherical, except where secondarily broken. The diameter is $480-550 \mu \mathrm{m}$. They are preserved through encrustation with a 5-7 $\mu \mathrm{m}$ thin layer consisting of fibrous apatite growing normal to the encrusted surface (Text-fig. 6C). In outer appearance, the embryos are either smooth and featureless or show the surface of the convoluted segmented body, more or less effaced. We interpret the completely smooth ones as embryos within a fertilization envelope. This is also suggested by the partial presence in some specimens of a smooth outer cover over a segmented body (Donoghue et al. 2006a, fig. 1h).

In the developed embryos, the body is clearly divisible into a head region (Text-fig. 6A, B, D), a thorax with about 75 transverse annulations, and a tail with posteriorly pointing spines (Text-fig. 6A, D-F).

The annuli are beset with short, conical spines, 50-60 $\mu \mathrm{m}$ long, that narrow into a sharp point distally (Textfig. 6G). Annuli may have 0-2 spines at irregular intervals, and there is a tendency for a spine position to repeat itself on every three segments. Occasionally, spines that are slightly longer $(80 \mu \mathrm{m})$ and more slender than the more medially placed ones are visible in lateral positions (Text-fig. $6 \mathrm{H}, \mathrm{I}$ ). The tail end bears two pairs of spines visible on the surface of the enrolled embryo (dorsal and lateral pairs), and another pair (ventral pair) beneath them (Text-fig. 6D-F).

Internally there are spoke-like structures corresponding in spacing to the external annulations (Text-fig. 6C, J). In the specimen in Text-fig. 6C they are separate from the body wall. As this specimen also contains numerous other encrusted filaments of less regular appearance (e.g., Text-fig. 6B, upper right), it cannot be excluded that these particular spokes are fortuitous effects of diagenesis. The specimen in Text-fig. 6J, however, shows spokes that are regularly arranged, and the two lower spokes are partly oblique to the body annulations. This supports the interpretation that the spokes are separate from the body wall and that, therefore, the annulations correspond to an internal segmentation. The spokes most likely represent an organ system that is not part of the body wall or mesentries, though the exact nature of this system remains unclear (see Bengtson and Yue 1997).

\section{Remarks.}

The 1983 references to M. secunda and M. prima are all nomina nuda, as they were not accompanied by any description or definition. In 1984, Val'kov and Karlova gave a description of M. secunda Valkov, 1983, 
with reference to one figured specimen, No. $762 / 37$ (PI. 2:15). In the plate caption, the same specimen is referred to as M. prima, Valkov 1983. Still lacking a description or definition, M prima thus remained a nomen nudum, and would otherwise have entered into objective synonymy with M. secunda, as Val'kov and Karlova (1984) named the only figured specimen $M$. secunda in the main text and $M$. prima in the figure caption. The figured specimen, No. 762/37, is the holotype by monotypy, as none other was figured or mentioned by Val'kov and Karlova (1984). This is in spite of a later designation by Val'kov (1987) of another specimen as holotype for M. secunda.

Khomentovsky et al. (1990, plate 4, figure 7) recorded Markuelia from 25-30 metres below the Pestrotsvet Formation at Dzhanda but the figured specimen is nothing more than a featureless globule. Khomentovsky and Karlova (1993) record Markuelia, but without illustration, from the Ust'-Yudoma Formation which underlies the Pestrotsvet Formation in southeastern Siberian Platform and is therefore of pre-Tommotian (Nemakit-Daldynian Stage), Purella Biozone age.

Markuelia hunanensis Dong and Donoghue in Dong et al., 2004

Text-fig. 7

v. 2004 Markuelia hunanensis Dong and Donoghue in Dong et al., pp. 237-40, figs 1a-f, 2a-f.

v.2005 Markuelia hunanensis; Donoghue and Dong, pp. 90-1, fig. 4f-i.

v.2005 Markuelia hunanensis; Dong et al., pp. 468-482, fig. 1a-i, 2a-e, g.

v.2006a Markuelia hunanensis; Donoghue et al., pp. 233-5.

v.2006b Markuelia hunanensis; Donoghue et al., pp. 681-2, fig. 2a-h.

v.2007 Markuelia hunanensis; Dong, pp. 930-934, figs 1a-I, 2a-i.

v.2008 Markuelia hunanensis; Peng and Dong, figs 1-4.

v.2009 Markuelia hunanensis; Dong, pp. 431-434, figs 2-5.

v.2009 Markuelia elegans Dong, pp. 434, fig. 6.

Holotype. GMPKU2010 
Type locality and horizon. Wangcun section, Yongshun County, western Hunan, South China. Bitiao Formation, Furongian, Upper Cambrian.

Additional material. GMPKU2007-19, 2021, 2205, 2213, 2214, 2218, 2222-5, 2227-32, 2237, 2238. All from the Wangcun section, Yongshun County, western Hunan, South China. All but GMPKU 2021 from Bitiao Formation, Furongian, Upper Cambrian. GMPKU 2021 from Middle Cambrian Huaqiao Formation.

Emended diagnosis. Markuelia species in which the embryo possesses few if any trunk spines, and in which the recurved pairs of tail spines are robust and proportionally elongate with respect to the width of trunk annuli.

Description. Markuelia hunanensis has the most simple body form among known species of Markuelia. It has unornamented scalids and no trunk spines in any of the specimens examined. The material is well preserved (showing features of the head, trunk and tail), to poorly preserved (with poorly defined annulations, and neither a head, nor a tail). The trunk cuticle has fine striations which are truncated at the boundaries between the annuli (Text-fig. 4A). Embryos are all spheroidal to sub-spheroidal and are preserved in apatite. All of the pre hatched larval specimens are coiled tightly within their eggs.

The anterior end has up to 40 scalids surrounding the mouth cone, but the first three rows around the mouth cone show the Markuelia scalid formula of 8,8 , and 9 scalids (Text-fig. 7D-K). The introvert may be inverted, with few scalids visible on the surface (Text-fig. 7A-C), to fully everted showing some, or all, of the scalids (Text-fig. 7L). The scalids are arranged in 5 to 8 rows. When the introvert is inverted the scalids point anteriorly (Text-fig. 7A-K), but when everted, the scalids lie against the body and point posteriorly (Text-fig. 7L). The direction in which the scalids point provides no taxonomic information. However, the arrangement of the scalids and the resulting symmetry does. It is possible to count the number of annulations in the trunk of four specimens; these have 56, 60, 64 and 68 annuli. The tail bears three pairs of tail spines; the dorsal pair are shorter than the other two pairs of spines (Text-fig. 7M). The preservation of specimens, in the best instances, preserves body openings, allowing the gut to be analysed (Text-fig. $7 \mathrm{~N}-\mathrm{O}$ ).

Remarks. The original diagnosis of Markuelia hunanensis Dong and Donoghue, 2004 is that of a species of Markuelia with six terminal, posterior spines arranged radially and away from a central depression or opening, lacking trunk spines in all examined specimens, and showing at least three overlapping rows of 
posteriorly directed circum-oral scalids (Dong et al., 2004). Based on additional well-preserved embryos, the posterior spines were revealed to be arranged bilaterally rather than radially, and that two of them (the dorsal pair) are smaller than the others (Dong et al., 2005).

Recently, in the light of synchrotron-radiation X-ray tomographic microscopy (SRXTM), the circum-oral scalids of one specimen were found to be within the embryo and situated on the inverted introvert, showing that Markuelia hunanensis was able to invert the introvert (Donoghue et al., 2006b). This indicates that the orientation of the circum-oral scalids is consistent with retraction of the introvert. The posteriorly directed circum-oral scalids only represent the late pre-hatching stage of Markuelia hunanensis, when the introvert was everted with the mouth cone and scalids fully exposed. Accordingly, the orientation of the circum-oral scalids should not be included in the diagnosis of Markuelia hunanensis.

Markuelia lauriei Haug et al., 2009

Text-figs 8-9

v.2006a Markuelia n. sp.; Donoghue et al., pp. 233-5; fig. 1a

v.2006 Markuelia sp.; Maas et al. Fig. 6a-b

v.2006 Markuelia sp.; Webster et al., fig. 1c

v.2007a Markuelia; Maas et al. fig. 7a

v²009 Markuelia lauriei Haug et al. pp. 306-312, figs 1a-b, 2a-g, 5a-d, 6a-b

Holotype. CPC 39947

Type locality and horizon. North Rogers Ridge, Georgina Basin, northern Australia. Monastery Formation, late Templetonian, Middle Cambrian.

Additional material. CPC 39946 (from the type locality).

Diagnosis. Markuelia species with slender protuberances on trunk annuli. 
Description. Like all other species of Markuelia the embryo is sub-spherical to discoidal and coiled in either an S-shaped or an inverted S-shaped loop with the head and tail juxtaposed (Text-fig. 8A-B, D-E, 9L-M). The thorax is composed of 86 and 72 transverse annulations, in the specimens CPC 39946 and CPC 39947 respectively. The thorax is flattened dorsoventrally and tapers towards the posterior end. The trunk is 125 $\mu \mathrm{m}$ in diameter. Some of the segments bear protuberances (Text-fig. $8 \mathrm{H}$ ), but they are slender and unlike the short, broad spines of $M$. secunda, with which they may be homologous. The trunk cuticle has fine striations that, unlike the striations observed in M. hunanensis, appear to be continuous across the boundaries between annuli (Text-fig. 8H). The embryo is preserved in apatite.

SRXTM revealed that the head bears scalids with the same number and symmetry in the first three scalid rows as observed in M. hunanensis; 8 in the first circumoral ring, 8 in the second and 9 in the third (Text-fig. 9F-K). In specimen CPC 39946 a total of 35 hollow scalids have been identified in total in 5 rings. The scalids point anteriorly when in the inverted position (Text-fig. 9A-K) and point in a posteriorly, and lay flat to the body as they are everted (Text-fig. 8C-D, F). One spine in CPC 39946 preserves two accessory spines, which were termed 'spinules' by Haug et al. (2009) (Text-fig. 8F; see also Haug et al. 2009, fig. 5c); these are far less numerous and densely spaced than the spinelets of $M$. spinulifera. SRXTM analysis also revealed that the head is preserved, but obscured by glue, in the holotype; the scalids are everted in this specimen (Text-fig. 9N-O).

The tail bears 6 dorso-ventrally recurved, equally sized, spines in three pairs at the terminal pole of the embryo (Text-figs 8G, 9D-E). The posterior spines are approximately $100 \mu \mathrm{m}$ long and $30 \mu \mathrm{m}$ at their widest point.

Remarks. There are four specimens of Markuelia known from Australia: CPC 39946 (specimen lost), CPC 39947, CPC AAAAA and CPC BBBBB. We consider CPC 39946 and CPC 39947 to belong to M. laurei and CPC AAAAA and CPC BBBBB to belong to $M$. waloszeki. There is some confusion due to the fact that these specimens were assigned specimen numbers while they were temporarily housed in Bonn and there are inconsistencies in the way these numbers have been used in the literature. Maas et al. (2006) figured specimen CPC 39946 as UB W 133 and CPC 39947 as UB W 132; both specimens were assigned to Markuelia sp. However, Donoghue et al. (2006) figured CPC 39946 as UB W 132, CPC AAAAA as UB W 
133 and CPC BBBBB without giving a specimen number; all three specimens were assigned to Markuelia $\mathrm{n}$. sp. Haug et al. (in press) established the name Markuelia laurei assigning CPC 39947 as the holotype and listing CPC 39946 as an additional specimen belonging to this species. In their synonomy list for M. laurei Haug et al. listed "v 2006 Markuelia n. sp. Donoghue et al., figs. 1A-D [CPC 39946, 39947]". As figure 1B-C of Donoghue et al. (2006) shows CPC AAAAA and 1D shows CPC BBBBB it is unclear which specimens Haug et al. consider to be synonyms of M. laurei.

\section{Markuelia spinulifera sp. nov.}

Text-fig. 10

v²005 Markuelia hunanensis; Dong et al., p. 472, fig. $2 f$

Derivation of name. spinulifera, Latin, carrying small spines, referring to the spinelets on the surface of the head scalids.

Holotype. GMPKU2234

Type locality and horizon. Wangcun section, Yongshun County, western Hunan, South China. Huaqiao Formation, Middle Cambrian.

Additional material. GMPKU2233, GMPKU2020 are designated paratypes. Wangcun section, Yongshun County, western Hunan, South China. Bitioa Formation, Furongian, Upper Cambrian.

Material. Three well-preserved specimens.

Occurrence. As for the type locality. Middle Cambrian Huaqiao Formation and Upper Cambrian (Furongian) Bitiao Formation, western Hunan, South China.

Diagnosis. Markuelia species in which the scalids are ornamented with numerous densely packed spinelets. 
Description. Only the embryos of the pre-hatching stage are preserved in our collection. The embryos are sufficiently tightly coiled into an inverted S-shaped loop that the lateral margins of the trunk are directly juxtaposed (Text-fig. 10A, D, G). The trunk varies in width from 138 to $263 \mu \mathrm{m}$. Transverse annulations (Text-fig. 10A-B, D, G) range in anterior-posterior length from approximately 21 to $32 \mu \mathrm{m}$. The posterior pole of the embryos is characterized by a terminal spine-bearing region surrounding a central opening. There is a total of three pairs of hollow spines surrounding the opening (Text-fig. 10A-D). Their long axes are parallel to, and concave margins and tips are directed away from, the anterior-posterior axis of the animal. The two narrower, straight spines (ventral pair) were positioned within the terminal opening and arranged bilaterally. The four larger curved spines (dorsal and lateral pairs), $75 \mu \mathrm{m}$ in length, $22 \mu \mathrm{m}$ in maximum width, are curved in approximately the same direction (towards the embryo; Text-fig.10A-D). The surface of the upper parts, including the tips, of the tail spines are smooth, whereas there are fine transverse ribs on the surface of the lower parts of the tail spines (Text-fig. 10C). The anterior pole is characterized by a terminal spinebearing region. The spines, ranging $36-61 \mu \mathrm{m}$ in length and $15-18 \mu \mathrm{m}$ in width, are posteriorly directed and arranged radially in four to six successive, partially overlapping rows. Broken scalids reveal that all the spines are hollow, and they are flattened in cross-sectional profile, oriented with the long axis at a tangent to the surface of the trunk (Fig.10A D-K). There are numerous spinelets on the surface of all the scalids. The spinelets range 1-6 $\mu \mathrm{m}$ in length and 0.8-1.2 $\mu \mathrm{m}$ in maximum width.

Remarks. The present species is characterized by the densely packed spinelets on the surface of the head scalids. This character is the essential difference from previously described species of Markuelia with known scalids. The spinelets in this species are far more numerous and densely packed than the structures described as spinules in M. lauriei. Although accessory structures are rare on the scalids of Cambrian taxa, spinelets have also been observed on the scalids of Ottoia prolifica by Conway Morris (1977, pl. 4, fig. 4).

Markuelia waloszekisp. nov.

Text-fig. 11A-G

v²006a Markuelia n. sp.; Donoghue et al., pp. 233-5; fig. 1b-d

Derivation of name. Names in honour of Prof. Dieter Waloszek who collected and recovered the specimens. 
Holotype. [Specimen in 11A-F Number]

Type locality and horizon. Middle Cambrian Beetle Creek Formation of Mt Murray, Georgina Basin, N. Australia.

Additional material. One specimen from the type locality number.

Occurrence. As for type locality.

Diagnosis. Markuelia species with broad conical spines on the trunk annuli and a tail in which the dorsal pair of tail spines is less than half the length of the ventral and lateral pairs.

Description. The embryo is sub-spherical to discoidal and the body is tightly coiled into an S-shaped loop (Text-fig. 11A, G). The anterior region is not preserved in either specimen. The annuli bear broad conical spines (Text-fig. 11E-F), which are similar in appearance to those of $M$. secunda. One specimen preserves the posterior, which bears three pairs of recurved spines (Text-fig. 11B-D). The outer lateral and ventral pairs are relatively broad-based and squat. The dorsal pair consists of spines that are also broad-based and are less than half as long as the other two pairs of spines. Both specimens are preserved in apatite, with the holotype preserving dumb bell shaped structures that may represent preserved bacteria (Text-fig. 4D).

Remarks. Markuelia waloszeki is most similar to M. secunda in that both taxa have broad conical spines on the trunk annuli and tail spines that have a relatively squat morphology. However, the present species differs from $M$. secunda in having very short dorsal tail spines and in having a sub-spherical to discoidal form like that of M. lauriei.

Markuelia sp.

Text-fig. $11 \mathrm{H}$

v.2006a Markuelia sp.; Donoghue et al., fig. 1e 
Material. A single specimen, USNM 530283.

Occurrence. Earliest Ordovician Vinini Formation of Battle Mountain, near Carlin, northern Nevada, USA.

Description. Embryo $460 \mu \mathrm{m}$ in diameter with an annulated trunk coiled into an S-shaped loop (Text-fig. $11 \mathrm{H})$. The annuli do not bear protuberances. The anterior is not preserved. The incompletely preserved tail has a pair of straight ventral spines and weakly curved dorsal and lateral spines; the lateral pair of spines are shorter than the other two pairs, though not to the same degree as in M. waloszeki (Text-fig. 11B-D).

Remarks. Donoghue et al. (2006a) figured a single specimen of Markuelia from Nevada. The specimen is most similar to $M$. hunanensis in that it lacks trunk protuberances and falls within the same size range. The tail possibly differs from that of $M$. hunanensis in having straighter spines.

\section{ACKNOWLEDGEMENTS}

We are indebted to the generosity of Prof. Dieter Waloszek for providing access to the specimens of $M$. lauriei and M. waloszeki. The University of Bonn Palaeontological Museum, and the Palaeontological Association for facilitating the recovery of specimens of Markuelia lauriei. Kristineberg Marine Station provided facilities for the recovery and culture of priapulid embryos and larvae. NSFC Project 40772008 (XPD), RFDP Project 20060001059 (XPD), LPS of Nanjing Institute of Geology and Palaeontology Grant 083101 (XPD), NERC Standard grants NE/C511256/1 (PCJD) and NE/F00348X/1 (PCJD). 


\section{1}

\section{REFERENCES}

AGUINALDO, A. M. A., TURBEVILLE, J. M., LINFORD, L. J., RIVERA, M. C., GAREY, J. R., RAFF, R. A. and LAKE, J. A. 1997. Evidence for a clade of nematodes, arthropods and other moulting animals. Nature, 387, 489-493.

BARTON, N. H., BRIGGS, D. E. G., EISEN, J. A., GOLDSTEIN, D. B. and PATEL, N. H. 2007. Evolution. Cold Spring Harbor Press, New York 833 pp.

BENGTSON, S. and YUE, Z. 1997. Fossilized metazoan embryos from the earliest Cambrian. Science, 277, 1645-1648.

BRIGGS, D. E. G. 2003. The role of decay and mineralization in the preservation of soft-bodied fossils. Annual Review of Earth and Planetary Science, 31, 275-301.

BRIGGS, D. E. G. and KEAR, A. J. 1993. Fossilization of soft tissue in the laboratory. Science, 259, 14391442.

1994. Decay and mineralisation of shrimps. PALAIOS, 9, 431-456.

and WILBY, P. R. 1996. The role of the calcium carbonate - calcium phosphate switch in the mineralization of soft-bodied fossils. Journal of the Geological Society, London, 153, 665-668.

CHAFETZ, H. S. and BUCZYNSKI, C. 1992. Bacterially induced lithifcation of microbial mats. PALAIOS, 7, 277-293.

COBBETT, A., WILKINSON, M. and WILLS, M. A. 2007. Fossils impact as hard as living taxa in parsimony analyses of morphology. Systematic Biology, 56, 753 - 766.

CONWAY MORRIS, S. 1977. Fossil priapulid worms. Special Papers in Palaeontology, 20, 1-95. 1998. Eggs and embryos from the Cambrian. BioEssays, 20, 676-682.

COSTA, M., DRAPER, B. W. and PRIESS, J. R. 1997. The role of actin filaments in patterning the Caenorhabditis elegans cuticle. Developmental Biology, 184, 373-384.

DONG, X.-P. 2007. Developmental sequence of the Cambrian embryo Markuelia. Chinese Science Bulletin, 52, 929-935.

2009. Cambrian fossil embryos from Western Hunan, South China. Acta Geologica Sinica, 83, 429439.

— and DONOGHUE, P. C. J. 2002. Affinity of the earliest bilaterian embryos. Palaeontology Newsletter, 51, 84-85.

_ CHENG, H. and LIU, J. 2004. Fossil embryos from the Middle and Late Cambrian period of Hunan, south China. Nature, 427, 237-240.

— CUNNINGHAM, J., LIU, J. and CHENG, H. 2005. The anatomy, affinity and phylogenetic significance of Markuelia. Evolution \& Development, 7, 468-482.

DONOGHUE, P. C. J. 2005. Saving the stem-group - a contradiction in terms. Paleobiology, 31, 553-558. 
and DONG, X.-P. 2005. Embryos and ancestors. In D. E. G. Briggs (ed). Evolving form and function: fossils and development. Yale Peabody Museum of Natural History, Yale University, New Haven, 81-99 pp.

— and PURNELL, M. A. 2009. Distinguishing heat from light in debate over controversial fossils. BioEssays, 31, 178-189.

KOUCHINSKY, A., WALOSZEK, D., BENGTSON, S., DONG, X.-P., VAL'KOV, A. K., CUNNINGHAM, J. A. and REPETSKI, J. E. 2006a. Fossilized embryos are widespread but the record is temporally and taxonomically biased. Evolution \& Development, 8, 232-238.

BENGTSON, S., DONG, X.-P., GOSTLING, N. J., HULDTGREN, T., CUNNINGHAM, J. A., YIN, C., YUE, Z., PENG, F. and STAMPANONI, M. 2006b. Synchrotron X-ray tomographic microscopy of fossil embryos. Nature, 442, 680-683.

DUNN, C. W., HEJNOL, A., MATUS, D. Q., PANG, K., BROWNE, W. E., SMITH, S. A., SEAVER, E., ROUSE, G. W., OBST, M., EDGECOMBE, G. D., SORENSEN, M. V., HADDOCK, S. H. D., SCHMIDT-RHAESA, A., OKUSU, A., KRISTENSEN, R. M., WHEELER, W. C., MARTINDALE, M. Q. and GIRIBET, G. 2008. Broad phylogenomic sampling improves resolution of the animal tree of life. Nature, 452, 745-749.

FUSCO, G. 2005. Trunk segment numbers and sequential segmentation in myriapods. Evolution \& Development, 7, 608-617.

GOSTLING, N. J., DONG, X.-P. and DONOGHUE, P. C. J. 2009. Ontogeny and taphonomy: and experimental taphonomy study of the development of the brine shrimp Artemia salina. Palaeontology, 52, 169-186.

THOMAS, C.-W., GREENWOOD, J. M., DONG, X.-P., BENGTSON, S., RAFF, E. C., RAFF, R. A., DEGNAN, B. M., STAMPANONI, M. and DONOGHUE, P. C. J. 2008. Deciphering the fossil record of early bilaterian embryonic development in light of experimental taphonomy. Evolution \& Development, 10, 339-349.

HAGADORN, J. W., XIAO, S., DONOGHUE, P. C. J., BENGTSON, S., GOSTLING, N. J., PAWLOWSKA, M., RAFF, E. C., RAFF, R. A., TURNER, F. R., YIN, C., ZHOU, C., YUAN, X., MCFEELY, M. B., STAMPANONI, M. and NEALSON, K. H. 2006. Cellular and subcellular structure of Neoproterozoic animal embryos. Science, 314, 291-294.

HARVEY, T. H. P., DONG, X.-P. and DONOGHUE, P. C. J. in press. Are palaeoscolecids ancestral ecdysozoans? Evolution \& Development.

HAUG, J. T., MAAS, A., WALOSZEK, D., DONOGHUE, P. C. J. and BENGTSON, S. 2009. A new species of Markuelia from the Middle Cambrian of Australia. Memoirs of the Association of Australasian Palaeontologists, 37, 303-313.

HENNIG, W. 1981. Insect phylogeny. John Wiley, New York 514 pp.

HOF, C. H. J. and BRIGGS, D. E. G. 1997. Decay and mineralisation of mantis shrimps (Stomatopoda: Crustacea) - a key to their fossil record. PALAIOS, 12, 420-438. 
HUANG, D., CHEN, J. Y. and VANNIER, J. 2006. Discussion on the systematic position of the Early Cambrian priapulomorph worms. Chinese Science Bulletin, 51, 243-249.

JONDELIUS, U., RUIZ-TRILLO, I., BAGUÑÀ, J. and RIUTORT, M. 2002. The Nemertodermatida are basal bilaterians and not members of the Platyhelminthes. Zoologica Scripta, 31, 201-215.

KEAR, A. J., BRIGGS, D. E. G. and DONOVAN, D. T. 1995. Decay and fossilization of nonmineralized tissue in coleoid cephalopods. Palaeontology, 38, 105-131.

KHOMENTOVSKY, V. V. and KARLOVA, G. A. 1993. Biostratigraphy of the Vendian-Cambrian beds and lower Cambrian boundary in Siberia. Geological Magazine, 130, 29-45.

— VAL'KOV, A. K. and KARLOVA, G. A. 1990. Novye dannye po biostratigrafii perekhodnykh vendkembrijskikh sloev $v$ bassejne srednegotecheniya r. Aldan (New data on the biostratigraphy of transitional Vendian-Cambrian strata in the middle reaches of the River Aldan). In V. V. Khomentovsky and A. S. Gibsher (eds). Poddniy dokembriy i ranniy paleozoy Sibiri. Voprosy regional'noy Stratigrafi Institut Geologiii i Geofiziki, Sibirskoe Otdelenie, Akademiya Nauk SSSR, Novosibirsk, 3-57 pp.

and NUZHNOV, S. V. 1983. Opornyj razrez perekhodnykh dokembrijsko-kembrijskikh otlozheniya nizovij r. Gonam. [Reference section for the transitional Precambrian-Cambrian deposits of the lower reaches of the River Gonam]. In V. V. Khomentovskij (ed). Pozdnij dokembrij i rannij paleozoj Sibiri - Vendskie otlozheniya. Inst. geol. i geof., SO AN SSSR, 24-36 pp.

LEMBURG, C. 1995. Ultrastructure of the introvert and associated structures of the larvae of Halicryptus spinulosus (Priapulida). Zoomorphology, 115, 11-29.

—. 1999. Ultrastrukurelle Untersuchungen an den Larven von Halicryptus spinulosus und Priapulus caudatus: Hypothesen zur Phylogenie der Priapulida und deren Bedeutung für die Evolution der Nemathelminthes. Cuvillier Verlag, Göttingen 393 pp.

MAAS, A., WALOSZEK, D., HAUG, J. T. and MÜLLER, K. J. 2007a. A possible larval roundworm from the Cambrian 'Orsten' and its bearing on the phylogeny of Cycloneuralia. Memoirs of the Association of Australasian Palaeontologists, 34, 499-519.

- HUANG, D., CHEN, J., WALOSZEK, D. and BRAUN, A. 2007b. Maotianshan-Shale nemathelminths -Morphology, biology, and the phylogeny of Nemathelminthes. Palaeogeography, Palaeoclimatology, Palaeoecology, 254, 288-306.

BRAUN, A., DONG, X.-P., DONOGHUE, P. C. J., MULLER, K. J., OLEMPSKA, E., REPETSKI, J. E., SIVETER, D. J., STEIN, M. and WALOSZEK, D. 2006. The 'Orsten'--More than a Cambrian Konservat-Lagerstatte yielding exceptional preservation. Palaeoworld, 15, 266-282.

MARTIN, D., BRIGGS, D. E. G. and PARKES, R. J. 2003. Experimental mineralization of invertebrate eggs and the preservation of Neoproterozoic embryos. Geology, 31, 39-42.

2004. Experimental attachment of sediment particles to invertebrate eggs and the preservation of soft-bodied fossils. Journal of the Geological Society, London, 161, 735-738. 2005. Decay and mineralization of invertebrate eggs. PALAIOS, 20, 562-572. 
MISSARZHEVSKY, V. V. 1989. Drevnejshie skeletnye okamenelosti i stratigrafiya pogranichnykh tolshch dokembriya i kembriya. [The oldest skeletal fossils and stratigraphy of the Precambrian-Cambrian boundary beds]. AN SSSR 1-237 pp.

NIELSEN, C. 1995. Animal evolution: interrelationships of the living phyla. Oxford University Press, New York $467 \mathrm{pp}$.

—. 2001. Animal evolution: interrelationships of the living phyla. Oxford University Press, Oxford 563 pp.

PARK, J. K., RHO, H. S., KRISTENSEN, R. M., KIM, W. and GIRIBET, G. 2006. First molecular data on the phylum Loricifera - An investigation into the phylogeny of Ecdysozoa with emphasis on the positions of Loricifera and Priapulida. Zoological Science, 23, 943-954.

PEEL, A. 2004. The evolution of arthropod segmentation mechanisms. BioEssays, 26, 1108-1116.

PENG, F. and DONG, X.-P. 2008. Application of Synchrotron X-Ray Tomography in the research of fossil embryo Markuelia. Acta Scientiarum Naturalium Universitatis Pekinensis, 44, 447-451.

RAFF, E. C., VILLINSKI, J. T., TURNER, F. R., DONOGHUE, P. C. J. and RAFF, R. A. 2006. Experimental taphonomy shows the feasibility of fossil embryos. Proceedings of the National Academy of Sciences, USA, 103, 5846-5851.

— SCHOLLAERT, K. L., NELSON, D. E., DONOGHUE, P. C. J., THOMAS, C.-W., TURNER, F. R., STEIN, B. D., DONG, X.-P., BENGTSON, S., HULDTGREN, T., STAMPANONI, M., CHONGYU, Y. and RAFF, R. A. 2008. Embryo fossilization is a biological process mediated by microbial biofilms. Proceedings of the National Academy of Sciences, 105, 19359-19364.

SAGEMANN, J., BALE, S. J., BRIGGS, D. E. G. and PARKES, R. J. 1999. Controls on the formation of authigenic mineral in association with decaying organic matter: an experimental approach. Geochemica et Cosmochemica Acta, 63, 1083-1095.

SØRENSEN, M. V., HEBSGAARD, M. B., HEINER, I., GLENNER, H., WILLERSLEV, E. and KRISTENSEN, R. M. 2008. New data from an enigmatic phylum: evidence from molecular sequence data supports a sister-group relationship between Loricifera and Nematomorpha. Journal of Zoological Systematics and Evolutionary Research, 46, 231-239.

STEINER, M., ZHU, M., LI, G., QIAN, Y. and ERDTMANN, B.-D. 2004. New early Cambrian bilaterian embryos and larvae from China. Geology, 32, 833-836.

VAL'KOV, A. K. 1983. Rasprostranenie drevnejshikh skeletnykh organizmov i korrelyatsiya nizhnej granitsy kembriya v yugo-vostochnoj chasti Sibirskoj platformy [Distribution of the oldest skeletal organisms and correlation of the lower boundary of the Cambrian in the southeastern part of the Siberian Platform]. In V. V. Khomentovsky, M. S. Yakshin and G. A. Karlova (eds). Pozdnij dokembrij i rannij paleozoj Sibiri, Vendskie otlozheniya. Inst. Geol. Geofiz. SO AN SSSR, Novosibirsk, 37-48 pp.

1987. Biostratigrafiya nizhnego kembriya vostoka Sibirskoj Platformy (Yudoma-Olenyokskij region). [Lower Cambrian biostratigraphy of the eastern part of the Siberian Platform (Yudoma-Olenyok region)]. Nauka, Moscow 136 pp.

- and KARLOVA, G. A. 1984. Fauna iz perekhodnykh vendsko-kembrijskikh sloev nizhnego techeniya r. Gonam. [The fauna of the transitional Vendian-Cambrian beds in the lower reaches of the River 
1

2

3

4

Gonam]. In V. V. Khomentovskij (ed). Stratigrafiya pozdnego dokembriya i rannego paleozoya. Srednyaya Sibir. Inst. Geol. Geof., Novosibirsk, 12-41 pp.

WEBSTER, B. L., COPLEY, R. R., JENNER, R. A., MACKENZIE-DODDS, J. A., BOURLAT, S. J., ROTASTABELLI, O., LITTLEWOOD, D. T. J. and TELFORD, M. J. 2006. Mitogenomics and phylogenomics reveal priapulid worms as extant models of the ancestral Ecdysozoan. Evolution \& Development, 8, 502-510.

WILBY, P. R. and BRIGGS, D. E. G. 1997. Taxonomic trends in the resolution of detail preserved in fossil phosphatised soft tissues. Geobios, 20, 493-502.

WILLS, M. A. 1998. Cambrian and recent disparity: the picture from priapulids. Paleobiology, 24, 177-199.

XIAO, S. and KNOLL, A. H. 1999. Fossil preservation in the Neoproterozoic Doushantuo phosphorite Lagerstätte, South China. Lethaia, 32, 219-240.

Z ZHANG, Y. and KNOLL, A. H. 1998. Three-dimensional preservation of algae and animal embryos in a Neoproterozoic phosphate. Nature, 391, 553-558. 


\section{Figure captions}

Text-fig. 1. Schematic drawings of a generalized Markuelia. A-B. The complete animal in an unfurled position as if it has hatched; scalids are illustrated in the everted position. A. Dorsal view. B. lateral view. C-F. Anterior region showing the process of eversion. C. Cut away view of the inverted position; scalids point anteriorly. D. The inverted position; some scalids are visible. E. Partially inverted position. F. Fully everted position; the mouth cone is visible.

Text-fig. 2. Cladograms arising from phylogenetic analyses. A. MPT from analysis of extant cycloneuralians and panarthropods only. B. MPT from analysis of taxa analysed in (A) plus Markuelia. C. MPT from analysis of taxa included in (B) plus representative stem-arthropods and a putative stem-onychophoran, but excluding tardigrades. D. Strict consensus tree from analysis of taxa in (C) plus a large number of extinct introvertans. E. Strict consensus tree from the reweighted analysis of taxa in (D). F. Strict consensus tree from analysis of taxa in (D) with Cricocosmia excluded.

Text-fig 3. Embryos of Markuelia hunanensis from the middle and late Cambrian, Wangcun, Hunan Province, south China at various stages of decay. A. Undecayed embryo exhibiting head (GMPKU2019). B. An otherwise well preserved specimen lacking a head (GMPKU2365). C. Detail of head region showing decay related collapse (GMPKU2010). D. Relatively undecayed embryo largely enveloped by chorion (GMPKU2021). E. Moderately decayed embryo (note that indistinct annulation may be due to proximity to the tail) (GMPKU2022). F. Strongly decayed embryo, features no longer recognisable (GMPKU2366). G. Chorion infested with filaments (GMPKU2367). H. Unbroken chorion (GMPKU2368). I. Deformed unbroken

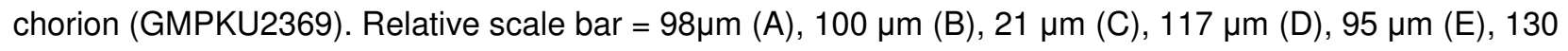
$\mu \mathrm{m}(\mathrm{F}), 140 \mu \mathrm{m}(\mathrm{G}), 105 \mu \mathrm{m}(\mathrm{H}), 108 \mu \mathrm{m}(\mathrm{I})$.

Text-fig. 4. Microfabrics exhibited by embryos of Markuelia hunanensis from the middle and late Cambrian, Wangcun, Hunan Province, south China (A-C) and Markuelia waloszeki from the Middle Cambrian Beetle Creek Formation of Mt Murray, Georgina Basin, N. Australia (D). A. Substrate microfabric (GMPKU2010). B. Intermediate microfabric (GMPKU2008). C. Microbial microfabric (GMPKU2021). D. Microbial microfabric with dumb bell shaped structures (CPC XXXX). Scale bar = $18 \mu \mathrm{m}(\mathrm{A}) ; 30 \mu \mathrm{m}(\mathrm{B}) ; 28 \mu \mathrm{m}(\mathrm{C}) 60 \mu \mathrm{m}(\mathrm{D})$. 
Text-fig. 6. Two embryos of Markuelia secunda Valkov, 1984 (L-forms), from section "Dvortsy”, basal part of the Pestrotsvet Formation, Yakutia, sample Sib73-15-SB. SEM (A-C, G-J) and SRXTM (D-F) images. A-G. NRM X2240 (also figured by Bengtson \& Yue 1997, fig. 2b; Dong et al. 2005, fig. 2i; and Donoghue et al. 2006 b, fig. 2i, j). A. View with tail end at upper middle. B. View with head end at upper middle. C. Detail of B, showing apatite-encrusted radiating spokes. D. Orientation like A, volume-texture rendering of whole body plus surface rendering of tail spines. E. Separate rendering of tail spines. F. Exploded view of E; top $=$ dorsal pair; middle = lateral pair; bottom = ventral pair. G. Detail of loop side, showing conical spines. H-J. NRM X2239 (also figured by Bengtson \& Yue 1997, fig. 2a; and Dong et al. 2005, fig. 2h). H. View of loop side. I. Detail of $\mathrm{H}$, showing interfingering marginal spines from adjacent trunk sides. J. Detail of $\mathrm{H}$, showing apatiteencrusting radiating spokes. Scale bar $=100 \mu \mathrm{m}(\mathrm{A}, \mathrm{B}, \mathrm{D}, \mathrm{H}) ; 80 \mu \mathrm{m}(\mathrm{E}, \mathrm{F}) ; 70 \mu \mathrm{m}(\mathrm{G}) ; 30 \mu \mathrm{m}(\mathrm{I}) ; 26 \mu \mathrm{m}(\mathrm{J})$; $22 \mu \mathrm{m}(\mathrm{C})$.

Text-fig. 7. Markuelia hunanensis Donoghue and Dong, 2004, (L-forms) from the Middle and Late Cambrian Bitiao Formation of Wangcun, Hunan Province, south China. SEM (A, L-M) and SRXTM (B-K, N-O) images. A-K. GMPKU2205 showing the introvert in the inverted position (also figured by Donoghue et al. $2006 \mathrm{~b}$ fig. 2a-f). A. Complete specimen. B. Complete specimen with scalids highlighted. C. Specimen rotated through $90^{\circ}$ from (B). D-K. Volume rendering of the scalids in lateral (D-G) and anterior (H-K) views. D,H. Eight scalids in the first row. E, I. 16 scalids in the first two rows. F, J. 25 scalids in the first three rows. G, K. All scalids. L. GMPKU2010 (holotype; also figured by Dong et al. 2004, fig. 1f, 2a-f; Dong et al. 2005, fig. 1i, 2a; and Peng and Dong 2008, fig. 3b) showing the everted introvert with spines pointing posteriorly. M. 
(also figured by Dong et al. 2004, fig. 1e; Donoghue et al. 2006 b, fig. 2g-h; and Peng and Dong 2008, figs $2 d-f, 3 a, 4 a-c)$. N. Reconstruction of posterior region with tail spines shown in yellow. O. Section showing the position of the digestive tract in red. Scale bar $=60 \mu \mathrm{m}(\mathrm{A}-\mathrm{C}) ; 50 \mu \mathrm{m}(\mathrm{D}-\mathrm{K}) ; 39 \mu \mathrm{m}(\mathrm{L}) ; 19 \mu \mathrm{m}(\mathrm{M}) ; 50 \mu \mathrm{m}(\mathrm{N}-$ O).

Text-fig. 8. Markuelia lauriei Haug et al., 2009 from North Rogers Ridge, Georgina Basin, northern Australia; Monastery Formation, late Templetonian, Middle Cambrian; CPC 39946 (also figured by Donoghue et al. 2006a, fig. 1a; Maas et al. 2006, fig. 6b; Webster et al. 2006, fig. 1c; Maas et al. 2007, fig. 7a; Haug et al. 2009, figs 1b, 2d, 5a-d, 6a-b; R-form). A-B, D-E. Complete specimen viewed from various orientations. C, F. Detailed views of the anterior region showing scalids. G. Detail of the posterior region. $\mathrm{H}$. Detail of the trunk showing slender protuberances. Scale bar $=50 \mu \mathrm{m}(\mathrm{A}-\mathrm{B}, \mathrm{D}-\mathrm{E}) ; 11 \mu \mathrm{m}(\mathrm{C}) ; 5 \mu \mathrm{m}(\mathrm{F}) ; 19 \mu \mathrm{m}(\mathrm{G}) ; 11 \mu \mathrm{m}(\mathrm{H})$.

Text-fig. 9. Markuelia lauriei Haug et al. 2009 from North Rogers Ridge, Georgina Basin, northern Australia; Monastery Formation, late Templetonian, Middle Cambrian. SRXTM reconstructions (A-K, N-O) and SEM images (L-M). A-K. CPC 39946 (R-form). A. Complete specimen with scalids (upper part) and tail spines (right hand side) highlighted. B-C. Complete specimen viewed from different orientations. D-E. Volume rendering of the tail spines. F-K. Volume rendering of the scalids (with the introvert in the inverted position) in anterior (F-H) and lateral (I-K) views. F, I. Eight scalids in the first row. G, J. 16 scalids in the first two rows. H, K. 25 scalids in the first three rows. L-O. CPC 39947 (holotype; also figured by Maas et al., 2006, fig. 6a; Haug et al. figs 1a, 2a-c, e-g; L-form). L-M. SEM images showing the complete specimen in different orientations. N. SRXTM image showing the anterior region. O. SRXTM image of complete specimen. Scale bar $=50 \mu \mathrm{m}(\mathrm{A}-\mathrm{C}) ; 18 \mu \mathrm{m}(\mathrm{D}-\mathrm{E}) ; 26 \mu \mathrm{m}(\mathrm{F}-\mathrm{K}) ; 55 \mu \mathrm{m}(\mathrm{L}-\mathrm{M}) ; 40 \mu \mathrm{m}$ (N-O).

Text-fig. 10. Markuelia spinulifera sp. nov. (A-K; R-form). A, embryo with tail (uppermost) head (upper right) juxtaposed (GMPKU2233; paratype) from Late Cambrian Bitiao Formation in Wangcun section, western Hunan, China. B, a close-up of A, showing the arrangement of the tail spines. C, a close-up of $B$, showing the fine ribs on the surface of the lower parts of the tail spines. The broken spine revealing the spines are hollow. D, Lateral-anterior view of A. E, a close-up of D, showing the posteriorly directed, radially arranged in six successive, partially overlapping rows of head scalids. F, a close-up of $E$, showing the spinlets on the surface of the scalids. G, embryo with head scalids (GMPKU2234; holotype) from Middle Cambrian Huaqiao 
Formation in Wangcun section, western Hunan, China. $\mathrm{H}$, a close-up of G, showing posteriorly directed, radially arranged in four successive, partially overlapping rows of head scalids. $\mathrm{F}$, a close-up of $\mathrm{H}$, showing the spinlets on the surface of the scalids. J, embryo with posteriorly directed, radially arranged in four successive, partially overlapping rows of head scalids. (GMPKU2020; paratype) from Late Cambrian Bitiao Formation in Wangcun section, western Hunan, China. K, a close-up of $\mathrm{J}$, showing the spinlets on the surface of the scalids. Scale bar $=76 \mu \mathrm{m}(\mathrm{A}), 31 \mu \mathrm{m}(\mathrm{B}), 15 \mu \mathrm{m}(\mathrm{C}), 67 \mu \mathrm{m}(\mathrm{D}), 33 \mu \mathrm{m}(\mathrm{E}), 8 \mu \mathrm{m}(\mathrm{F}), 52 \mu \mathrm{m}$ (G), $21 \mu \mathrm{m}(\mathrm{H}), 11 \mu \mathrm{m}(\mathrm{I}), 67 \mu \mathrm{m}(\mathrm{J}), 6 \mu \mathrm{m}(\mathrm{K})$.

Text-fig. 11. Markuelia waloszeki sp. nov. from the Middle Cambrian Beetle Creek Formation of Mt Murray, Georgina Basin, N. Australia (A-G) and Markuelia sp. from the Earliest Ordovician Vinini Formation of Battle Mountain, near Carlin, northern Nevada, USA (H). SEM (A, E-H) and SRXTM (B-D) images. A-F. CPC XXXX (holotype; also figured by Donoghue et al. 2006a fig. 1b-c; L-form). A. Complete specimen. B. Complete specimen with tail spines highlighted. C. Tail spines. D. Exploded view of tail region; top = dorsal pair; middle $=$ lateral pair; bottom = ventral pair. E. Detail of the posterior region. F. Detail of the trunk showing broad conical spines. G. CPC XXXX (also figured by Donoghue et al. 2006a, fig. 1d). Complete specimen. H. USNM 530283 (also figured by Donoghue et al. 2006a, fig. 1e; L-form) complete specimen. Scale bar = 70 $\mu \mathrm{m}(\mathrm{A}-\mathrm{B}) ; 35 \mu \mathrm{m}(\mathrm{C}, \mathrm{D}) ; 34 \mu \mathrm{m}(\mathrm{E}) ; 39 \mu \mathrm{m}(\mathrm{F}) ; 82 \mu \mathrm{m}(\mathrm{G}) ; 132 \mu \mathrm{m}(\mathrm{H})$. 


\section{APPENDIX}

Our phylogenetic analysis was based on that of Harvey et al. (in press). Below we provide the codings for Markuelia. For character descriptions and for the codings of other taxa, please refer to Harvey et al. (in press).

\section{Markuelia}

$1110111000-0-\ldots 12$ ? ? $0000--? ? 00$ ? 1111 ? 1?1??????????????1 $0--$ ? ? ? ? 000 ? 000 ?? ? ? ? ? ? ? ? ? ? 00110 

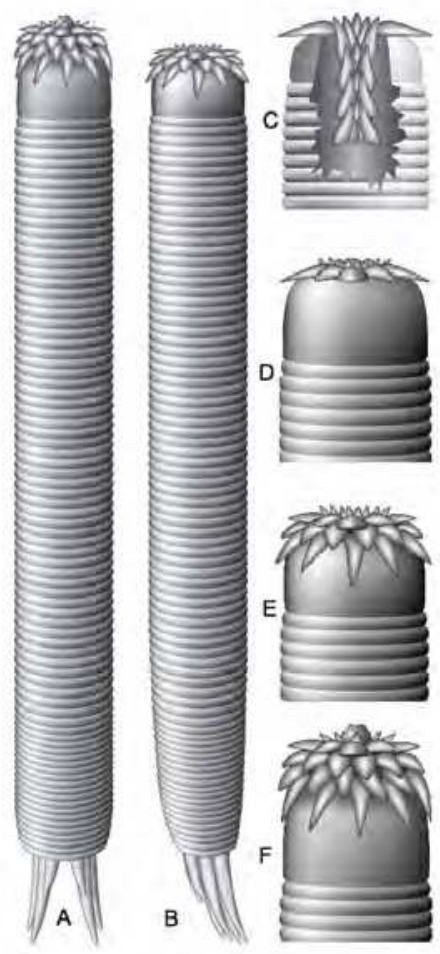

Text-fig. 1. Schematic drawings of a generalized Markuelia. A-B. The complete animal in an unfurled position as if it has hatched; scalids are illustrated in the everted position. A. Dorsal view. B. lateral view. C-F. Anterior region showing the process of eversion. C. Cut away view of the inverted position; scalids point anteriorly. D. The inverted position; some scalids are visible. E. Partially inverted position. F. Fully everted position; the mouth cone is visible. $209 \times 297 \mathrm{~mm}(150 \times 150 \mathrm{DPI})$ 

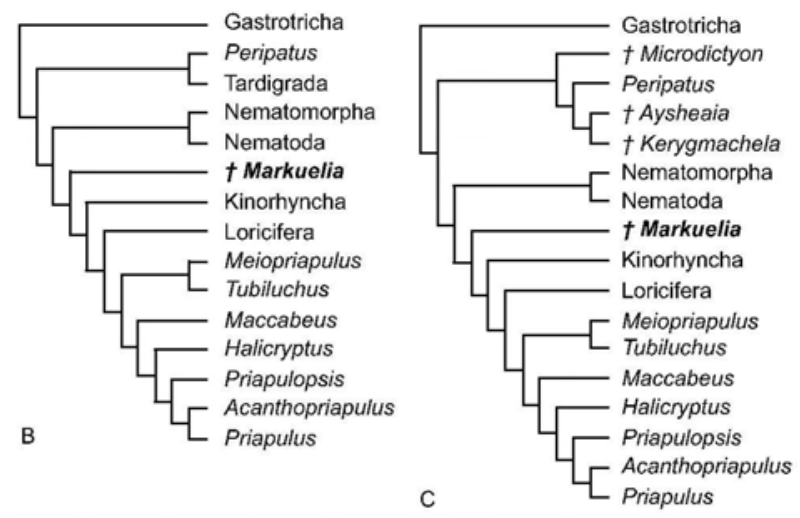

D

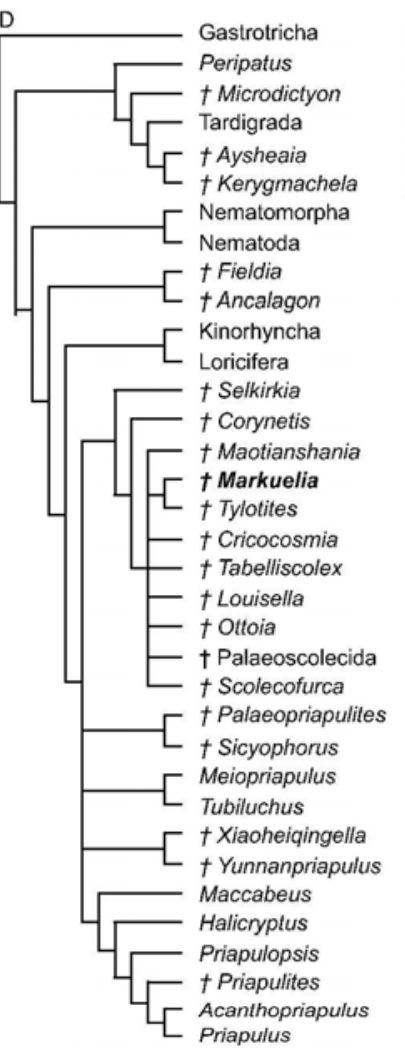

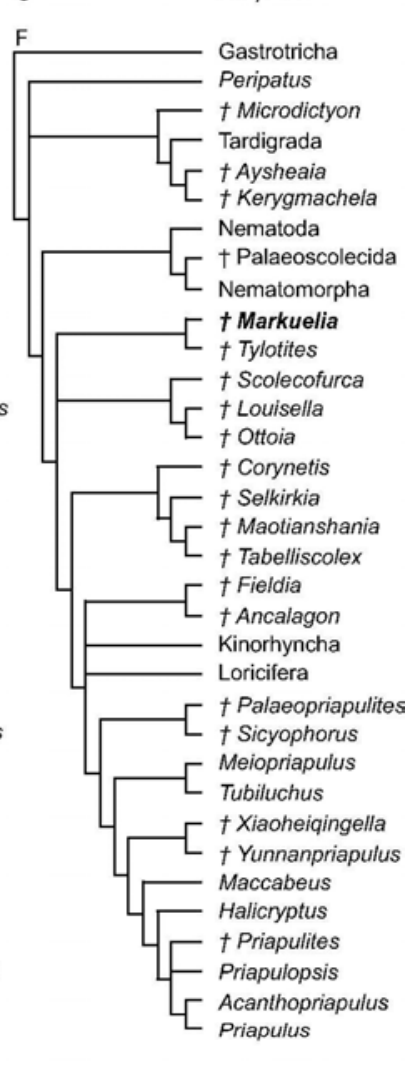

Text-fig. 2. Cladograms arising from phylogenetic analyses. A. MPT from analysis of extant cycloneuralians and panarthropods only. B. MPT from analysis of taxa analysed in (A) plus Markuelia. C. MPT from analysis of taxa included in (B) plus representative stem-arthropods and a putative stem-onychophoran, but excluding tardigrades. D. Strict consensus tree from analysis of taxa in (C) plus a large number of extinct introvertans. E. Strict consensus tree from the reweighted analysis of taxa in (D). F. Strict consensus tree from analysis of taxa in (D) with Cricocosmia excluded. $191 \times 250 \mathrm{~mm}(600 \times 600 \mathrm{DPI})$ 


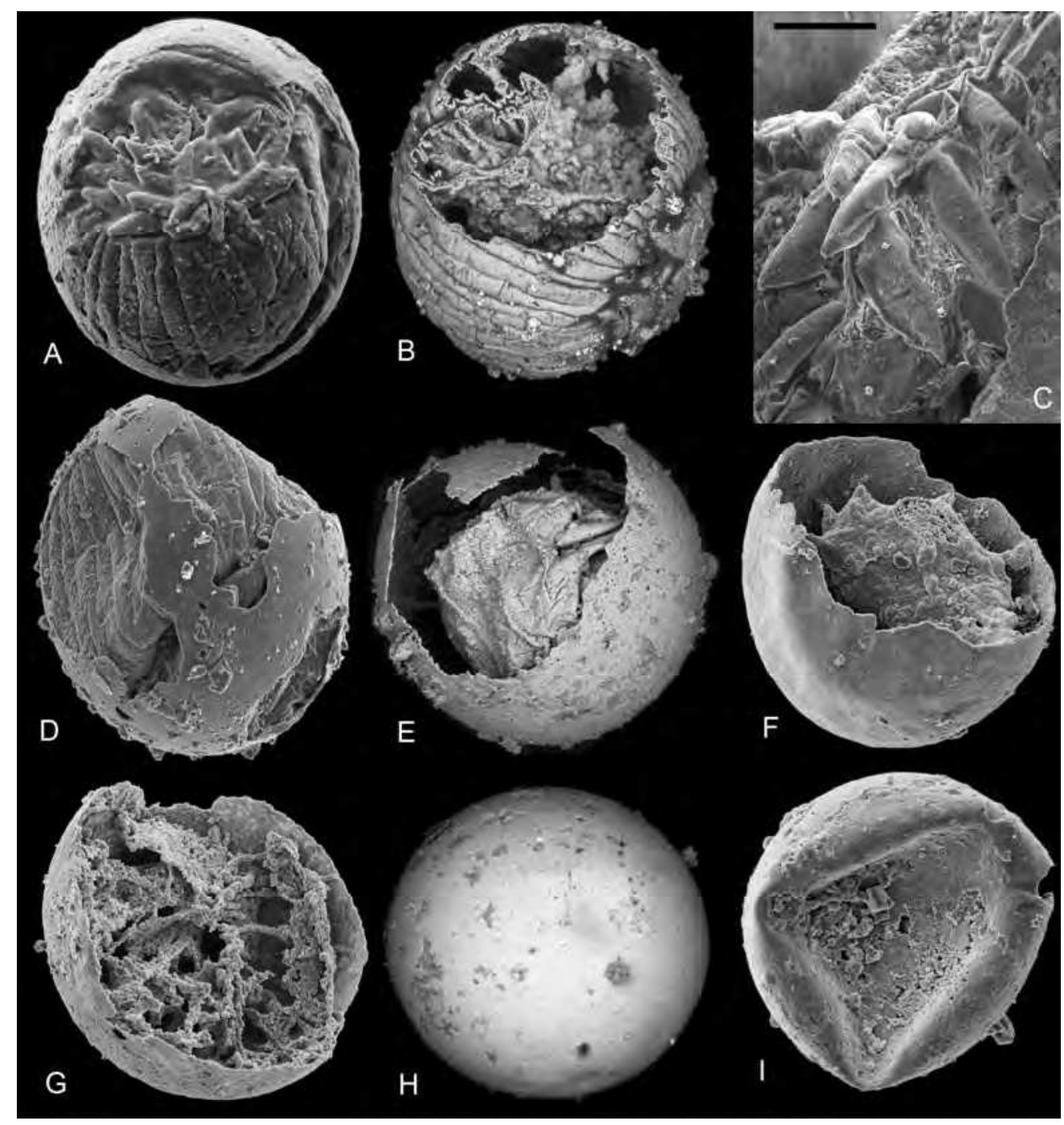

Text-fig 3. Embryos of Markuelia hunanensis from the middle and late Cambrian, Wangcun, Hunan Province, south China at various stages of decay. A. Undecayed embryo exhibiting head (GMPKU2019). B. An otherwise well preserved specimen lacking a head (GMPKU2365). C. Detail of head region showing decay related collapse (GMPKU2010). D. Relatively undecayed embryo largely enveloped by chorion (GMPKU2021). E. Moderately decayed embryo (note that indistinct annulation may be due to proximity to the tail) (GMPKU2022). F. Strongly decayed embryo, features no longer recognisable (GMPKU2366). G. Chorion infested with filaments (GMPKU2367). H. Unbroken chorion

(GMPKU2368). I. Deformed unbroken chorion (GMPKU2369). Relative scale bar $=98 \mu \mathrm{m}(\mathrm{A}), 100$ $\mu \mathrm{m}(\mathrm{B}), 21 \mu \mathrm{m}(\mathrm{C}), 117 \mu \mathrm{m}(\mathrm{D}), 95 \mu \mathrm{m}(\mathrm{E}), 130 \mu \mathrm{m}$ (F), $140 \mu \mathrm{m}$ (G), $105 \mu \mathrm{m}(\mathrm{H}), 108 \mu \mathrm{m}(\mathrm{I})$. $167 \times 176 \mathrm{~mm}(322 \times 322 \mathrm{DPI})$ 


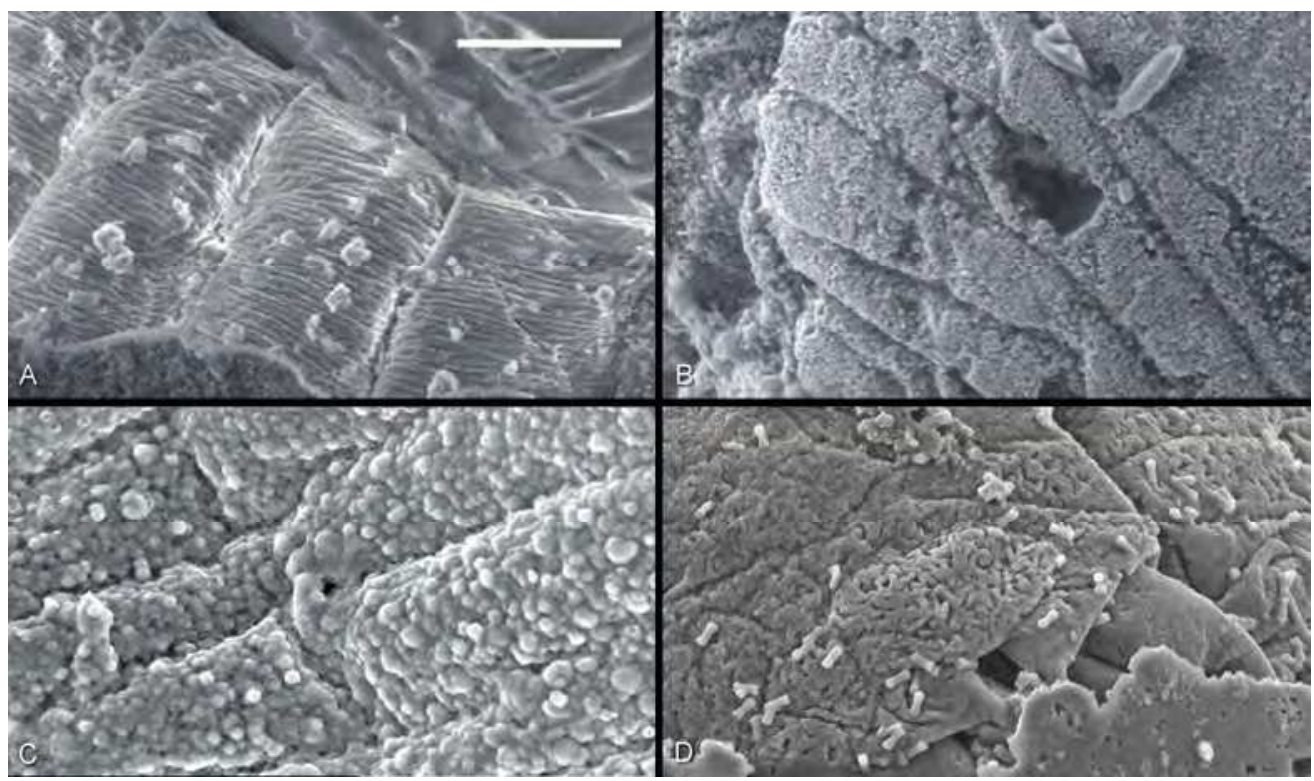

Text-fig. 4. Microfabrics exhibited by embryos of Markuelia hunanensis from the middle and late Cambrian, Wangcun, Hunan Province, south China (A-C) and Markuelia waloszeki from the Middle Cambrian Beetle Creek Formation of Mt Murray, Georgina Basin, N. Australia (D). A. Substrate microfabric (GMPKU2010). B. Intermediate microfabric (GMPKU2008). C. Microbial microfabric (GMPKU2021). D. Microbial microfabric with dumb bell shaped structures (CPC XXXX). Scale bar $=$ $18 \mu \mathrm{m}(\mathrm{A}) ; 30 \mu \mathrm{m}(\mathrm{B}) ; 28 \mu \mathrm{m}(\mathrm{C}) 60 \mu \mathrm{m}(\mathrm{D})$. $166 \times 98 \mathrm{~mm}(350 \times 350 \mathrm{DPI})$ 


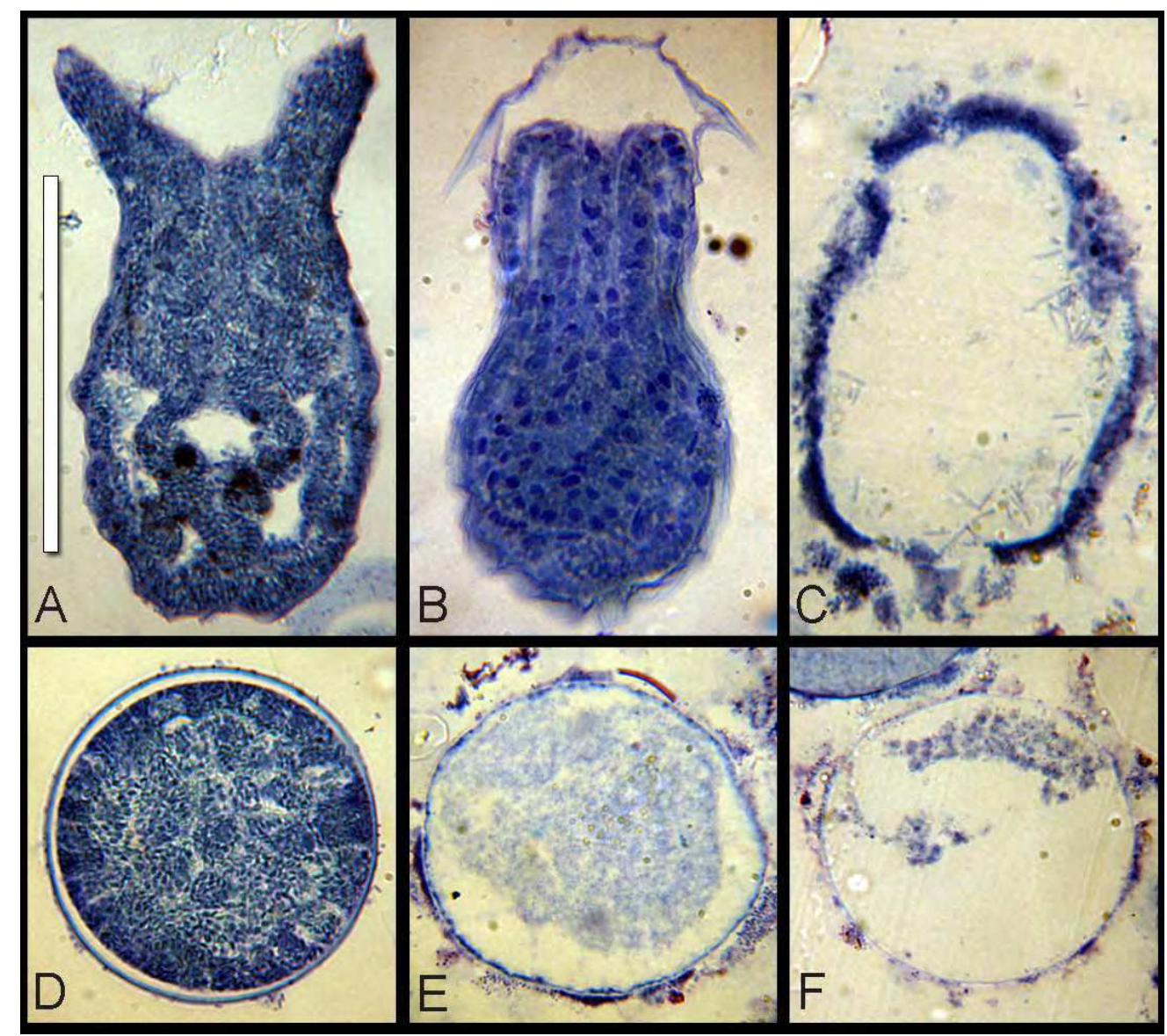

Text-fig. 5. Experimental taphonomy of embryos and larvae of Priapulus caudatus. A-C. Thin sections of larvae at various stages of decay. A. Fresh larva with muscles and gut distinct. B. Muscles and gut begin to lose integrity; cells detach from the cuticle so that the spines evert when the introvert is inverted. C. Muscles and gut decay within the cuticle leaving only the cuticle, which has a thick coating of bacteria. D-F. Thin sections of embryos at various stages of decay. D. Fresh embryo with distinct cells. E. Cells begin to coalesce and shrink; the chorion may become less spherical as decay progresses. F. As decay progresses the chorion contains only cuticle and shrunken decayed organic matter. Scale bar $=50 \mu \mathrm{m}$. $79 \times 71 \mathrm{~mm}(350 \times 350 \mathrm{DPI})$ 


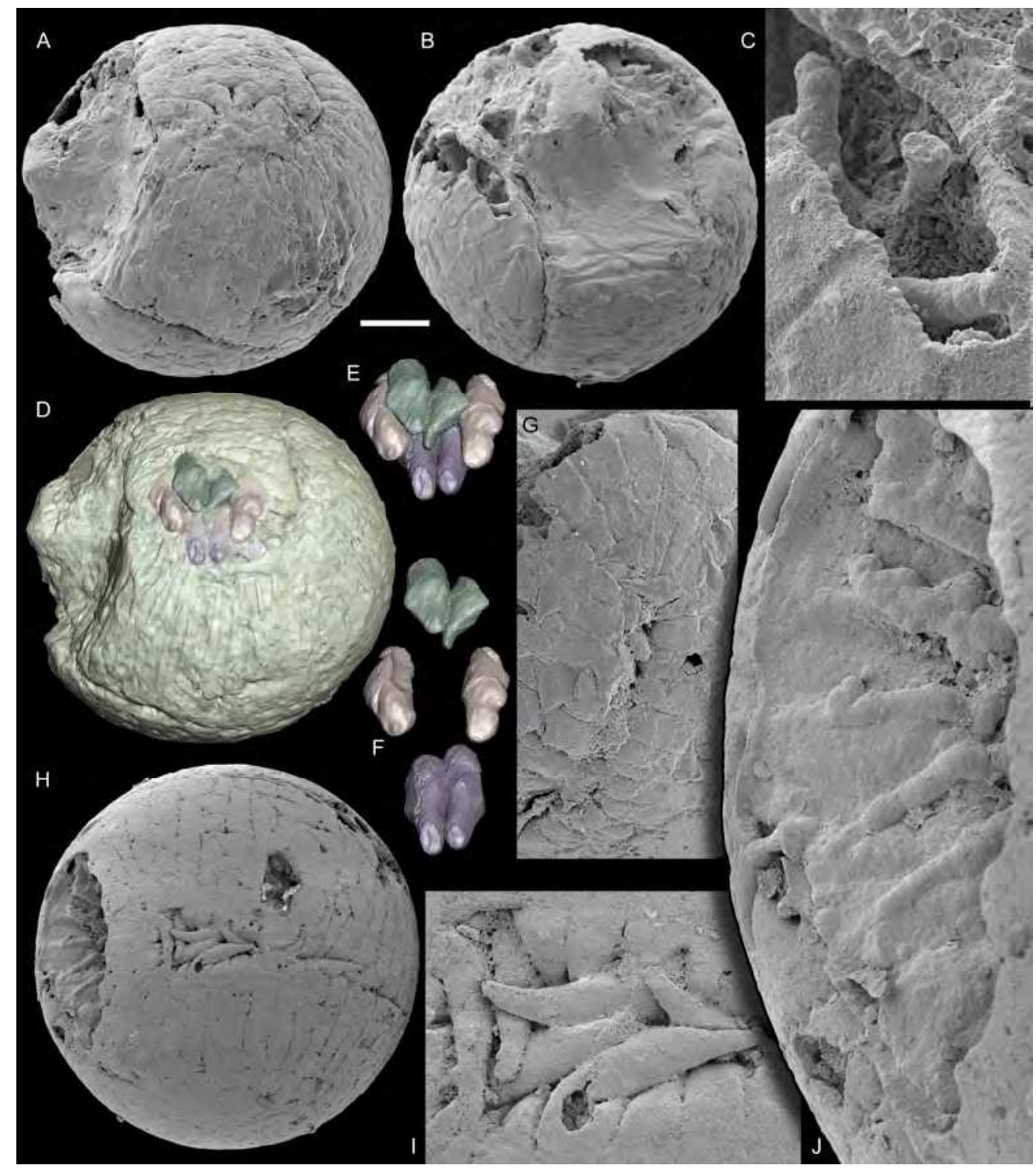

Text-fig. 6. Two embryos of Markuelia secunda Valkov, 1984 (L-forms), from section "Dvortsy", basal part of the Pestrotsvet Formation, Yakutia, sample Sib73-15-SB. SEM (A-C, G-J) and SRXTM (D-F) images. A-G. NRM X2240 (also figured by Bengtson \& Yue 1997, fig. 2b; Dong et al. 2005, fig. 2i; and Donoghue et al. 2006b, fig. 2i, j). A. View with tail end at upper middle. B. View with head end at upper middle. C. Detail of B, showing apatite-encrusted radiating spokes. D. Orientation like $A$, volume-texture rendering of whole body plus surface rendering of tail spines. $E$. Separate rendering of tail spines. F. Exploded view of E; top = dorsal pair; middle = lateral pair; bottom = ventral pair. G. Detail of loop side, showing conical spines. H-J. NRM X2239 (also figured by Bengtson \& Yue 1997, fig. 2a; and Dong et al. 2005, fig. 2h). H. View of loop side. I. Detail of H, showing interfingering marginal spines from adjacent trunk sides. J. Detail of $H$, showing apatiteencrusting radiating spokes. Scale bar $=100 \mu \mathrm{m}(\mathrm{A}, \mathrm{B}, \mathrm{D}, \mathrm{H}) ; 80 \mu \mathrm{m}(\mathrm{E}, \mathrm{F}) ; 70 \mu \mathrm{m}(\mathrm{G}) ; 30 \mu \mathrm{m}(\mathrm{I})$; $26 \mu \mathrm{m}(\mathrm{J}) ; 22 \mu \mathrm{m}(\mathrm{C})$. $166 \times 189 \mathrm{~mm}(350 \times 350 \mathrm{DPI})$ 


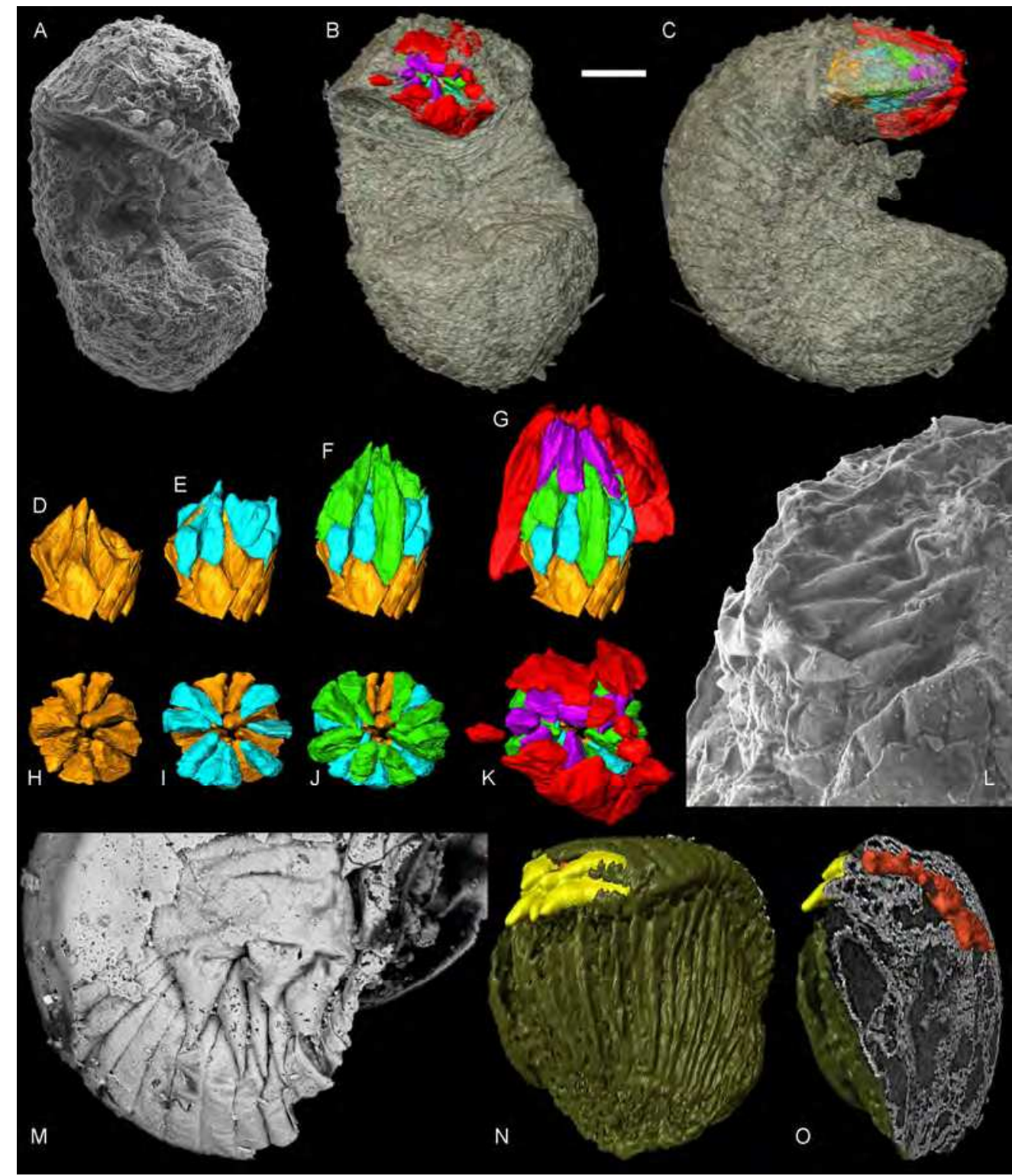

Text-fig. 7. Markuelia hunanensis Donoghue and Dong, 2004, (L-forms) from the Middle and Late Cambrian Bitiao Formation of Wangcun, Hunan Province, south China. SEM (A, L-M) and SRXTM (B$\mathrm{K}, \mathrm{N}-\mathrm{O}$ ) images. A-K. GMPKU2205 showing the introvert in the inverted position (also figured by Donoghue et al. 2006b fig. 2a-f). A. Complete specimen. B. Complete specimen with scalids highlighted. C. Specimen rotated through $90^{\circ}$ from (B). D-K. Volume rendering of the scalids in lateral $(D-G)$ and anterior $(H-K)$ views. $D, H$. Eight scalids in the first row. $E, I$. 16 scalids in the first two rows. F, J. 25 scalids in the first three rows. G, K. All scalids. L. GMPKU2010 (holotype; also figured by Dong et al. 2004, fig. 1f, 2a-f; Dong et al. 2005, fig. 1i, 2a; and Peng and Dong 2008, fig. $3 b$ ) showing the everted introvert with spines pointing posteriorly. M. GMPKU2017 (also figured by Dong et al. 2005, fig. 2b) showing the six posterior spines. N-O. GMPKU2011 (also figured by Dong et al. 2004, fig. 1e; Donoghue et al. 2006b, fig. 2g-h; and Peng and Dong 2008, figs 2d-f, 3a, $4 a-c)$. N. Reconstruction of posterior region with tail spines shown in yellow. O. Section showing the position of the digestive tract in red. Scale bar $=60 \mu \mathrm{m}(\mathrm{A}-\mathrm{C}) ; 50 \mu \mathrm{m}(\mathrm{D}-\mathrm{K}) ; 39 \mu \mathrm{m}(\mathrm{L}) ; 19 \mu \mathrm{m}$ 


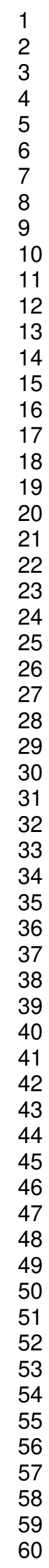

(M); $50 \mu \mathrm{m}(\mathrm{N}-\mathrm{O})$. $166 \times 196 \mathrm{~mm}(350 \times 350 \mathrm{DPI})$ 


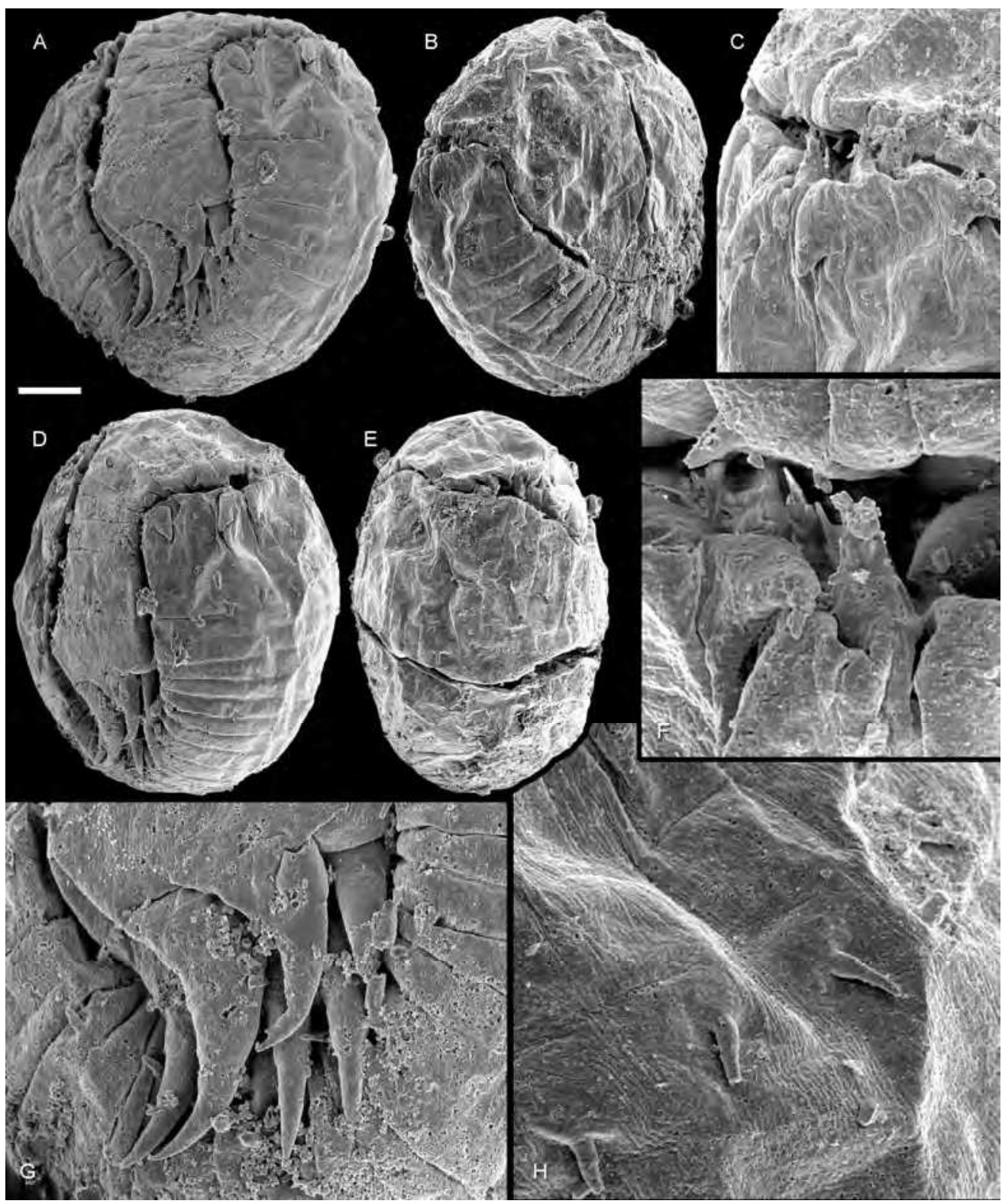

Text-fig. 8. Markuelia lauriei Haug et al., 2009 from North Rogers Ridge, Georgina Basin, northern Australia; Monastery Formation, late Templetonian, Middle Cambrian; CPC 39946 (also figured by Donoghue et al. 2006a, fig. 1a; Maas et al. 2006, fig. 6b; Webster et al. 2006, fig. 1c; Maas et al. 2007, fig. 7a; Haug et al. 2009, figs 1b, 2d, 5a-d, 6a-b; R-form). A-B, D-E. Complete specimen viewed from various orientations. C, F. Detailed views of the anterior region showing scalids. G.

Detail of the posterior region. $\mathrm{H}$. Detail of the trunk showing slender protuberances. Scale bar $=50$ $\mu \mathrm{m}(\mathrm{A}-\mathrm{B}, \mathrm{D}-\mathrm{E}) ; 11 \mu \mathrm{m}(\mathrm{C}) ; 5 \mu \mathrm{m}(\mathrm{F}) ; 19 \mu \mathrm{m}(\mathrm{G}) ; 11 \mu \mathrm{m}(\mathrm{H})$. $166 \times 199 \mathrm{~mm}(300 \times 300 \mathrm{DPI})$ 


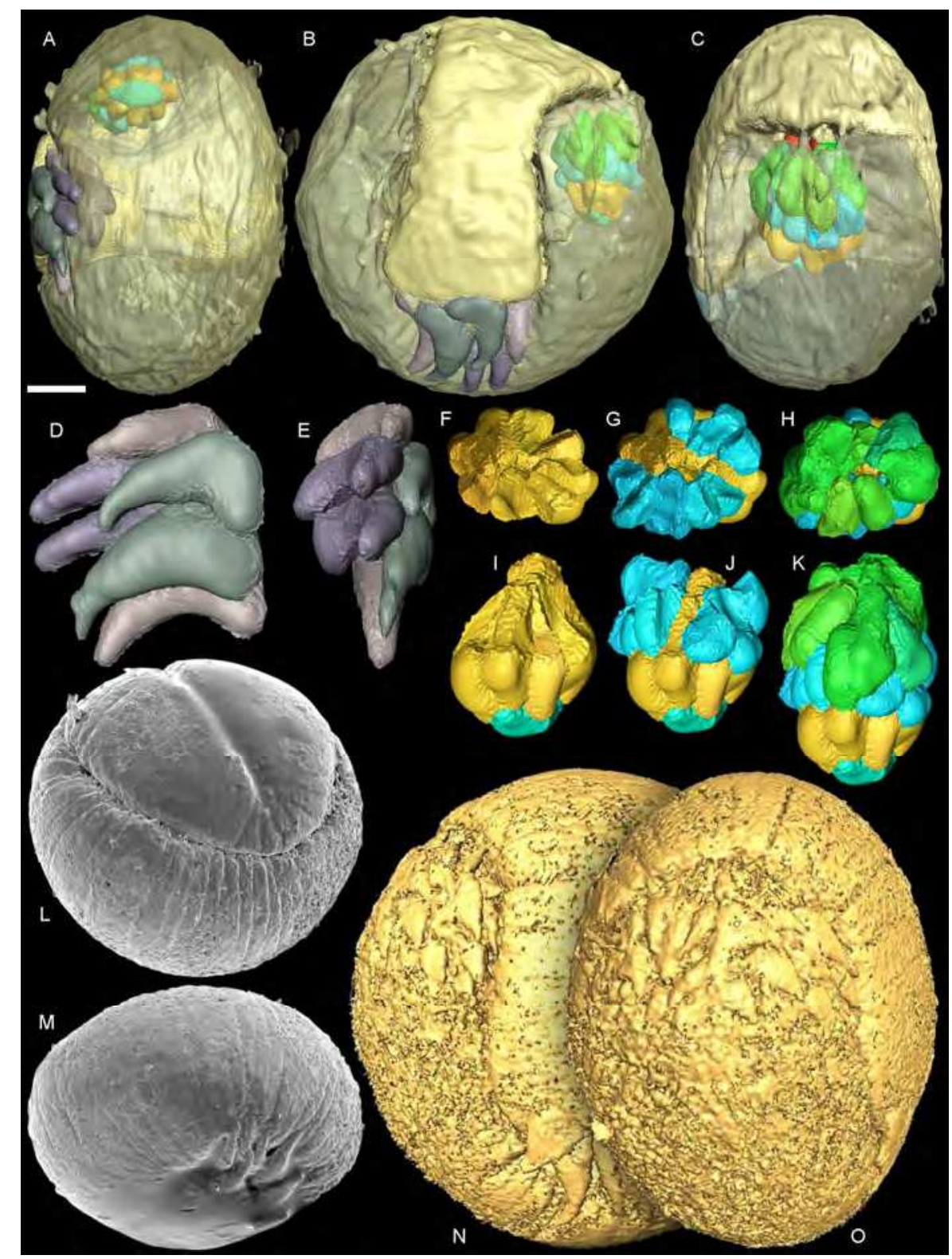

Text-fig. 9. Markuelia lauriei Haug et al. 2009 from North Rogers Ridge, Georgina Basin, northern Australia; Monastery Formation, late Templetonian, Middle Cambrian. SRXTM reconstructions (A-K, $\mathrm{N}-\mathrm{O}$ ) and SEM images (L-M). A-K. CPC 39946 (R-form). A. Complete specimen with scalids (upper part) and tail spines (right hand side) highlighted. B-C. Complete specimen viewed from different orientations. D-E. Volume rendering of the tail spines. F-K. Volume rendering of the scalids (with the introvert in the inverted position) in anterior (F-H) and lateral (I-K) views. F, I. Eight scalids in the first row. G, J. 16 scalids in the first two rows. H, K. 25 scalids in the first three rows. L-O. CPC 39947 (holotype; also figured by Maas et al., 2006, fig. 6a; Haug et al. figs 1a, 2a-c, e-g; L-form).

L-M. SEM images showing the complete specimen in different orientations. N. SRXTM image showing the anterior region. O. SRXTM image of complete specimen. Scale bar $=50 \mu \mathrm{m}(\mathrm{A}-\mathrm{C}) ; 18$ $\mu \mathrm{m}(\mathrm{D}-\mathrm{E}) ; 26 \mu \mathrm{m}(\mathrm{F}-\mathrm{K}) ; 55 \mu \mathrm{m}(\mathrm{L}-\mathrm{M}) ; 40 \mu \mathrm{m}(\mathrm{N}-\mathrm{O})$. $166 \times 224 \mathrm{~mm}(300 \times 300 \mathrm{DPI})$ 
1

2

3

4

5

6

7

8

9

10

11

12

13

14

15

16

17

18

19

20

21

22

23

24

25

26

27

28

29

30

31

32

33

34

35

36

37

38

39

40

41

42

43

44

45

46

47

48

49

50

51

52

53

54

55

56

57

58

59

60

Palaeontology 


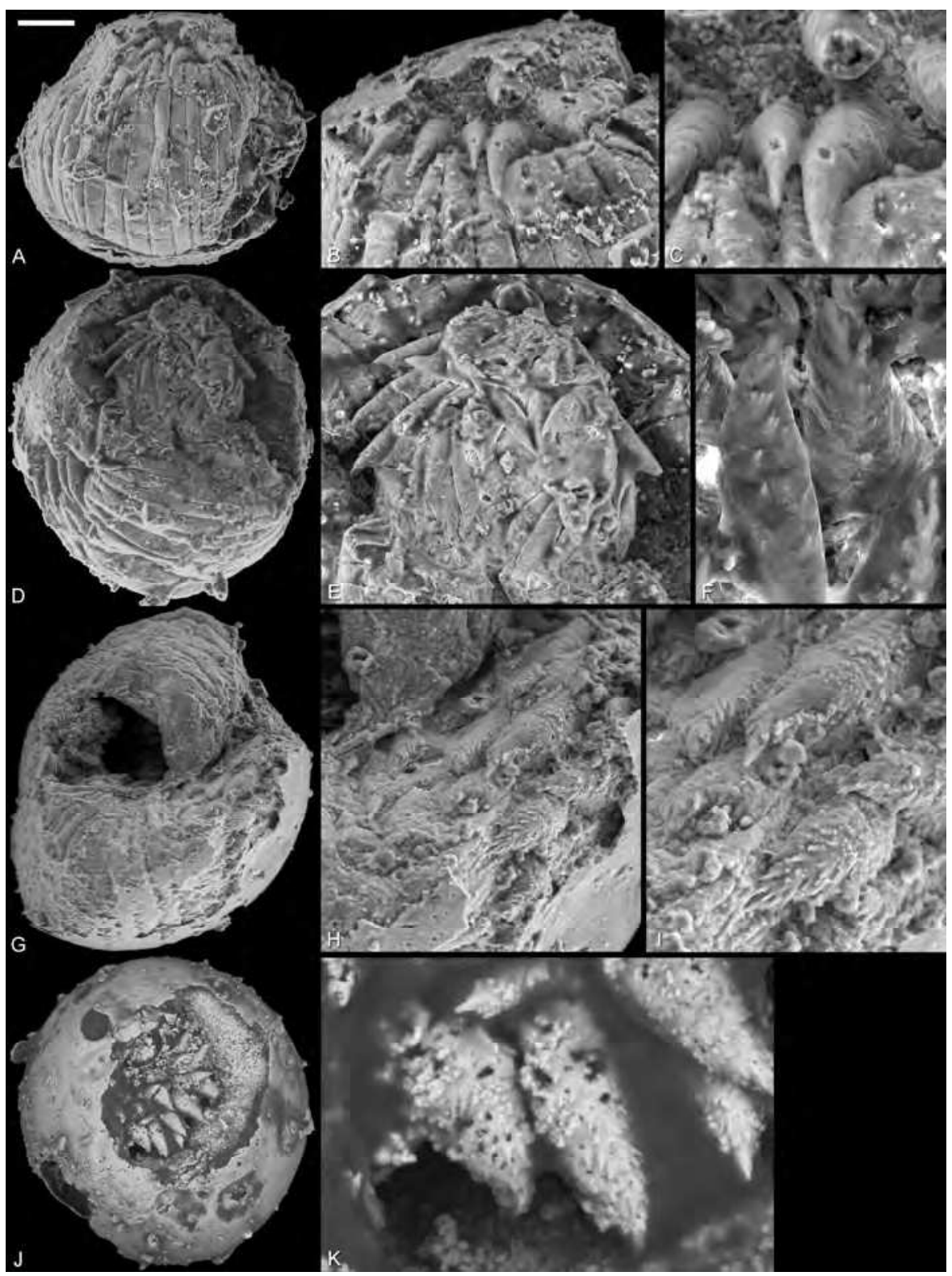

Text-fig. 10. Markuelia spinulifera sp. nov. (A-K; R-form). A, embryo with tail (uppermost) head (upper right) juxtaposed (GMPKU2233; paratype) from Late Cambrian Bitiao Formation in Wangcun section, western Hunan, China. B, a close-up of A, showing the arrangement of the tail spines. C, a close-up of $B$, showing the fine ribs on the surface of the lower parts of the tail spines. The broken spine revealing the spines are hollow. D, Lateral-anterior view of $A$. E, a close-up of $D$, showing the posteriorly directed, radially arranged in six successive, partially overlapping rows of head scalids. $F$, a close-up of $E$, showing the spinlets on the surface of the scalids. $G$, embryo with head scalids (GMPKU2234; holotype) from Middle Cambrian Huaqiao Formation in Wangcun section, western Hunan, China. $\mathrm{H}$, a close-up of $\mathrm{G}$, showing posteriorly directed, radially arranged in four successive, partially overlapping rows of head scalids. $\mathrm{F}$, a close-up of $\mathrm{H}$, showing the spinlets on the surface of

the scalids. J, embryo with posteriorly directed, radially arranged in four successive, partially overlapping rows of head scalids. (GMPKU2020; paratype) from Late Cambrian Bitiao Formation in 
Wangcun section, western Hunan, China. $K$, a close-up of $J$, showing the spinlets on the surface of the scalids. Scale bar $=76 \mu \mathrm{m}(\mathrm{A}), 31 \mu \mathrm{m}(\mathrm{B}), 15 \mu \mathrm{m}(\mathrm{C}), 67 \mu \mathrm{m}(\mathrm{D}), 33 \mu \mathrm{m}(\mathrm{E}), 8 \mu \mathrm{m}(\mathrm{F}), 52 \mu \mathrm{m}$ (G), $21 \mu \mathrm{m}(\mathrm{H}), 11 \mu \mathrm{m}(\mathrm{I}), 67 \mu \mathrm{m}(\mathrm{J}), 6 \mu \mathrm{m}(\mathrm{K})$. $166 \times 223 \mathrm{~mm}(430 \times 430 \mathrm{DPI})$

1

2

5

6

7

8

9

10

11

12

13

14

15

16

17

18

19

20

21

22

23

24

25

26

27

28

29

30

31

32

33

34

35

36

37

38

39

40

41

42

43

44

45

46

47

48

49

50

51

52

53

54

55

56

57

58

59

60 


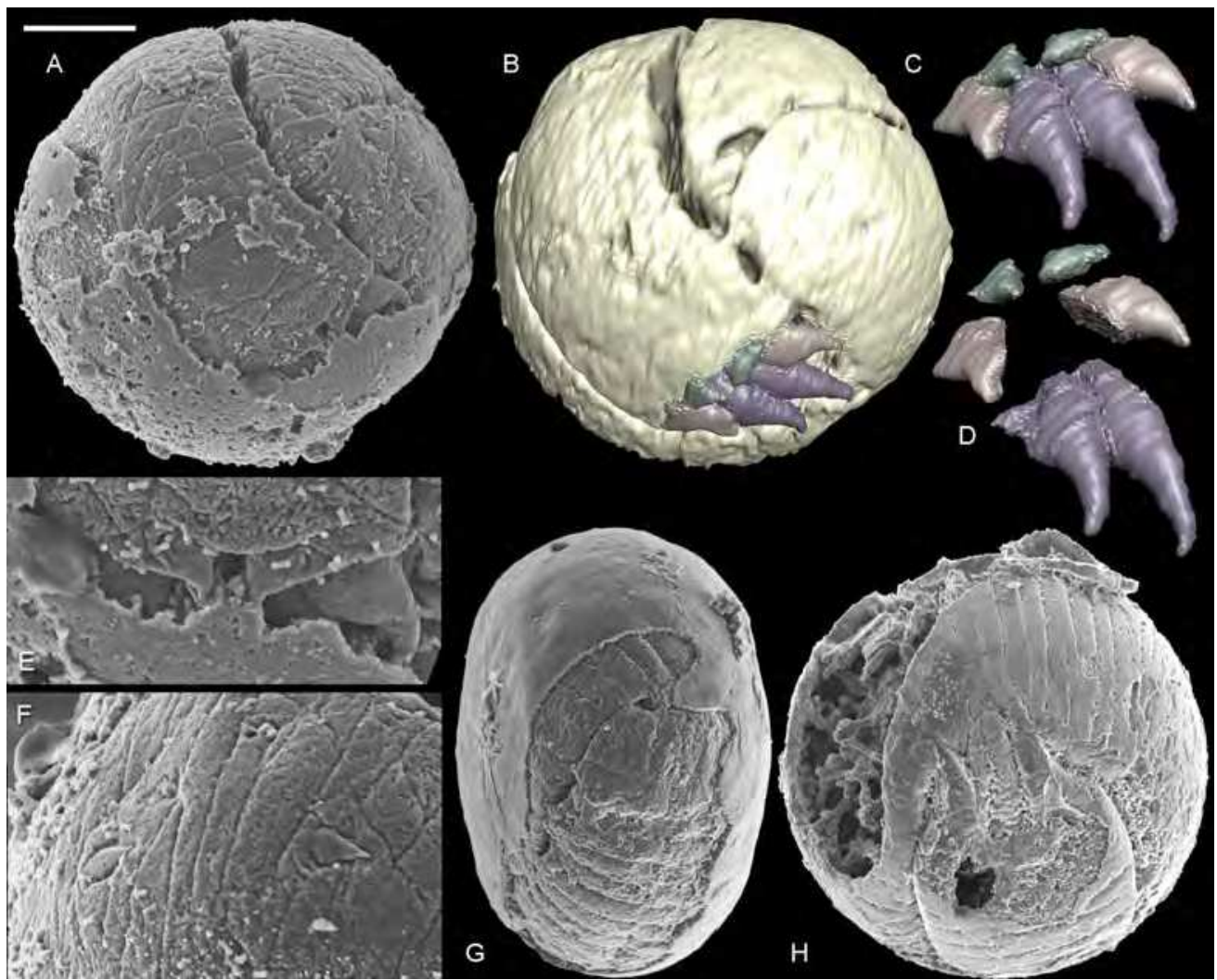

Text-fig. 11. Markuelia waloszeki sp. nov. from the Middle Cambrian Beetle Creek Formation of Mt Murray, Georgina Basin, N. Australia (A-G) and Markuelia sp. from the Earliest Ordovician Vinini Formation of Battle Mountain, near Carlin, northern Nevada, USA (H). SEM (A, E-H) and SRXTM (BD) images. A-F. CPC XXXX (holotype; also figured by Donoghue et al. 2006a fig. 1b-C; L-form). A. Complete specimen. B. Complete specimen with tail spines highlighted. C. Tail spines. D. Exploded view of tail region; top = dorsal pair; middle = lateral pair; bottom = ventral pair. E. Detail of the posterior region. F. Detail of the trunk showing broad conical spines. G. CPC XXXX (also figured by Donoghue et al. 2006a, fig. 1d). Complete specimen. H. USNM 530283 (also figured by Donoghue et al. 2006a, fig. 1e; L-form) complete specimen. Scale bar $=70 \mu \mathrm{m}(\mathrm{A}-\mathrm{B}) ; 35 \mu \mathrm{m}(\mathrm{C}, \mathrm{D}) ; 34 \mu \mathrm{m}$ (E); $39 \mu \mathrm{m}(\mathrm{F}) ; 82 \mu \mathrm{m}(\mathrm{G}) ; 132 \mu \mathrm{m}(\mathrm{H})$. $166 \times 134 \mathrm{~mm}(300 \times 300 \mathrm{DPI})$ 